\title{
L'esperienza del paesaggio nella natural visualization
}

\author{
Cristian Farinella
}

Abstract

Dagli anni 2000, nella visualizzazione architettonica (archviz) si può osservare la diffusione di una tendenza nota come visualizzazione naturale, in cui la strategia di comunicazione primaria risiede nella creazione di immagini e animazioni in computer grafica che sfruttano il contributo estetizzante del paesaggio. Di conseguenza, molte aree dell'industria 3D si sono specializzate nella creazione di assets e nello sviluppo di soluzioni dedicate al rendering della vegetazione e di paesaggi. Le campagne di scansione intraprese da Quixel, con le sue megascans, sono tra le più adottate nei CG film, con particolare riguardo ai paesaggi nordici e all'Islanda. II legame simbolico e partecipativo dell'osservatore con la natura rappresenta il caso più evidente di sublimazione del paesaggio e ritorno ai temi romantici. Questo linguaggio viene oggi impiegato dal CG artist - e nello specifico dal 3D architectural visualizer - alla stessa maniera del pittore e del prospettivista del passato. Per questo motivo, il presente studio vuole proporre un'analisi e un confronto tra le immagini realizzate in computer grafica (CGI) e le opere pittoriche che, sebbene concepite in epoche passate, si rivelano ancora contemporanee nella concezione, nelle strategie di comunicazione, e nella struttura compositiva adottata.

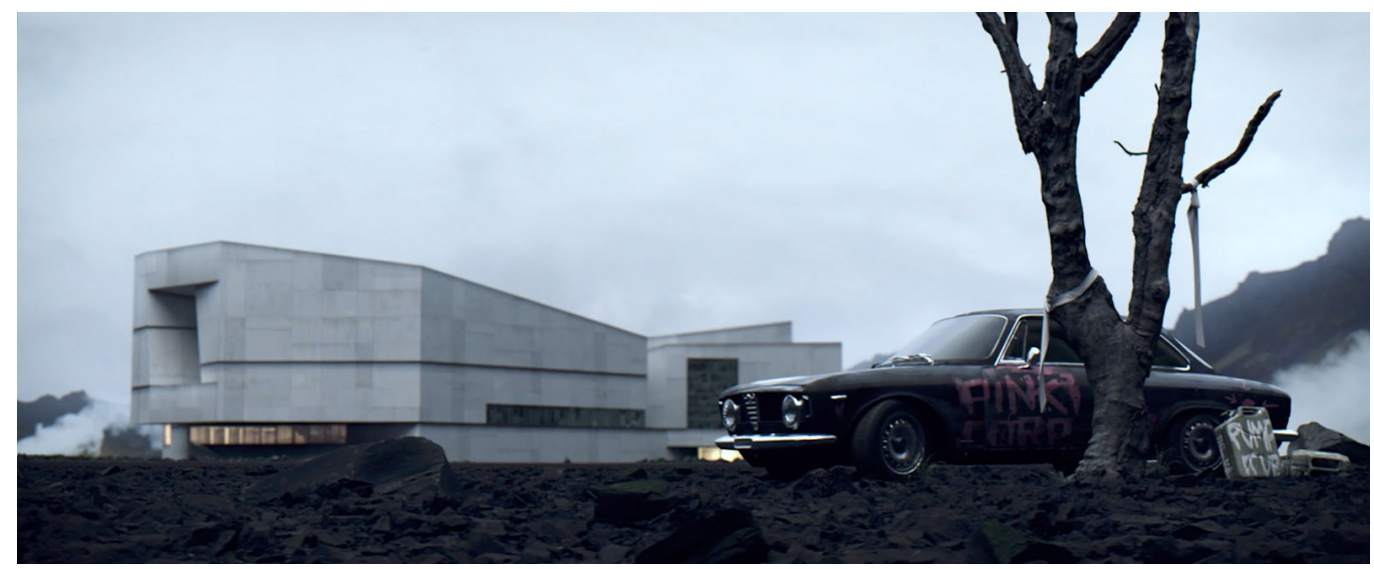




\section{Introduzione}

Di pari passo con l'ampliamento delle possibilità espressive offerte dalle tecnologie informatiche e dal digital imaging, i trend della visualizzazione in campo architettonico sembrano circoscrivere il loro interesse alle atmosfere drammatiche in uso nelle più consolidate correzioni colore cinematografiche. Cieli plumbei, contrasti marcati, riduzione della gamma cromatica con una forte inclusione dei neri, ribadiscono come il cinema sia ancora il medium con più seguito in campo architettonico. Gli artisti del 3D si lasciano ispirare non soltanto dalle armonie cromatiche del cinema, quanto dal suo stesso linguaggio figurativo, per finire con il rintracciare e replicare anche le componenti tecniche, i meccanismi di ripresa, i movimenti di camera, l'illuminazione della scena; tutto questo senza incorrere nelle limitazioni fisiche presenti nel mondo reale. La natura artificiale, di cui la visualizzazione fa uso nelle proprie immagini al computer, si mostra quale termine di paragone estetico con la realtà percepita da parte dell'osservatore. La natural visualization, qui presa in esame, è una tendenza che a partire dagli anni duemila esaspera il salto di scala tra contesto antropico e naturale, per ricalcare gran parte dell'immaginario pittoresco e romantico dell'arte tradizionale. In particolare, l'artista del 3D fa esplicito riferimento al vedutismo settecentesco, alla corrente topografica inglese, ai più celebri pittori romantici, per rintracciare e ripresentare, con nuovi modelli interpretativi, la ricchezza di soluzioni visive della tradizione artistica del passato.

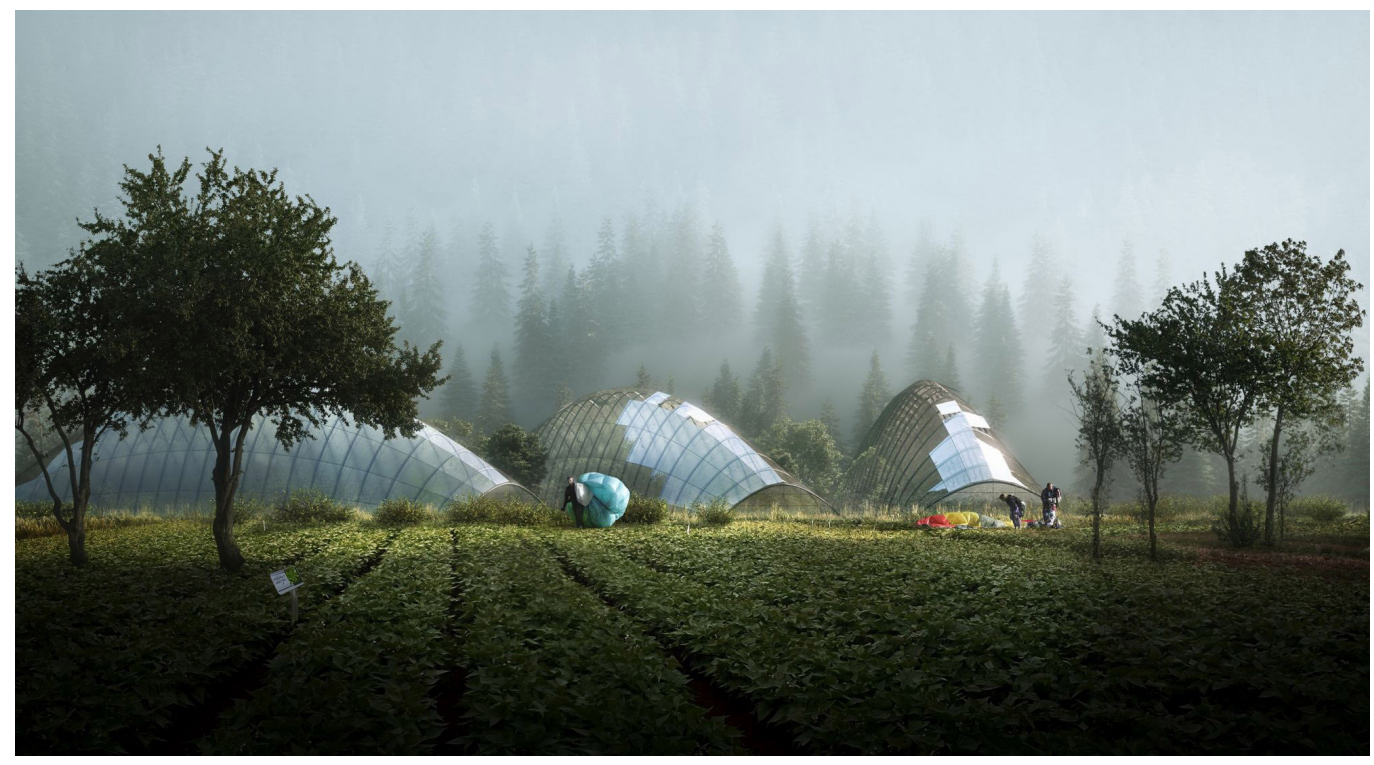

\section{II paesaggio nella natural visualization}

Senza poterci soffermare sulla figura recente del prospettivista architettonico e dei suoi legami culturali con la tradizione pittorica - la cui trattazione viene rimandata in bibliografia [l] - il termine natural visualization, adottato soltanto di recente in archviz (acronimo di visualizzazione architettonica), viene da tempo impiegato nell'ambito della computer science e del digital imaging, per descrivere la naturalezza di un'immagine in virtù della sua spatial frequency. La misurazione descrive, mediante le trasformazioni di Fourier, la variazione dell'intensità lungo una distanza. Nelle visualizzazioni definite 'naturali' il valore della luminosità viene rappresentato in forma di diagramma, il cui andamento regolare denota la naturalezza visiva dell'immagine. Nell'indagine condotta dai computer scientist Haroz e Ma [2], nella quale sono state prese in esame alcune immagini rappresentative, sono state definite 'naturali' soltanto quelle il cui andamento sul grafico della spatial frequency è risultato regolare. 
Di conseguenza, appaiono naturali le immagini degli animali, delle foreste, delle montagne o del mare, al contrario appaiono innaturali tutti i pattern grafici e i disturbi. Se una nozione rigorosa di cosa possa considerarsi naturale nelle immagini può sembrare superflua - o ridondante - non bisogna dimenticare che le prime immagini generate al computer erano caratterizzate da un largo uso di pattern grafici, visualizzazioni wireframe e di artefatti, mentre è soltanto a partire dagli anni Duemila che si registrano le prime esperienze di visualizzazioni naturali nel rendering architettonico. Queste ultime sono caratterizzate dal rifiuto dei cliché e delle soluzioni stereotipate in uso negli anni Novanta [3] che si focalizzavano su una correzione del colore molto pronunciata e su una gamma dinamica estesa. II ricorso alla tecnica del compositing contraddistingue sia il nuovo approccio naturale che il precedente di tipo grafico-illustrativo, tuttavia, nel linguaggio della natural visualization si possono individuare almeno due aspetti peculiari: la presenza costante della natura e uno storytelling coerente con i soggetti messi in scena.

II primo aspetto riguarda le visualizzazioni che ricorrono a un uso estatico-contemplativo del paesaggio, riconducibile alle opere pittoriche del Romanticismo ottocentesco, un movimento artistico che ha contribuito, più di ogni altro, alla formazione di un immaginario estetico di riferimento per la rappresentazione della natura e dei suoi connotati. II secondo aspetto peculiare della natural visualization è, invece, quello legato allo storytelling. Nell'archviz, il termine si riferisce "all'arte del raccontare storie attraverso immagini", un'espressione usata in maniera ricorrente nei siti web delle agenzie che si occupano di visualizzazione. L'uso della narrazione visiva è dunque impiegata come una vera e propria strategia di comunicazione persuasiva delle architetture rappresentate. In questo caso, il carattere naturale dato alle ambientazioni è anche suggerito dalle azioni compiute dai soggetti raffigurati, ossia da situazioni in cui non sono presenti particolari forzature e stranezze.

Per comprendere questo nuovo paradigma, basti pensare ai rendering architettonici ricchi invece di veri e propri meme. Alcuni sono divenuti così famosi da aver dato vita a pagine e gruppi di discussione online. In passato, sono stati i kayaks (la tipica canoa degli Inuit) l'elemento straniante a essere ricorrente nelle visualizzazioni di molti progetti, come nel caso della Golden State Warriors Arena (2012) di Snøhetta e AECOM a San Francisco, e nella Salling Tower (20/3) di Dorte Mandrup Arkitekter in Danimarca [4]. Altrettanto numerose, nei concorsi di architettura, sono state le immagini che hanno mostrato un'ampia gamma di oggetti volanti, tra sonde meteorologiche, mongolfiere e palloncini. La natural visualization rappresenta pertanto un cambiamento radicale nel processo di sviluppo dell'immagine, non soltanto nelle finalità estetiche, ma anche negli aspetti pratici e operativi dell'elaborazione dei rendering. Durante il tipico workflow di una visualizzazione naturale, le parti renderizzate sono sempre meno estese nello spazio bidimensionale dell'immagine, e si ricorre in maniera frequente all'uso di fotografie e di pitture digitali al posto dei modelli 3D. Nono-

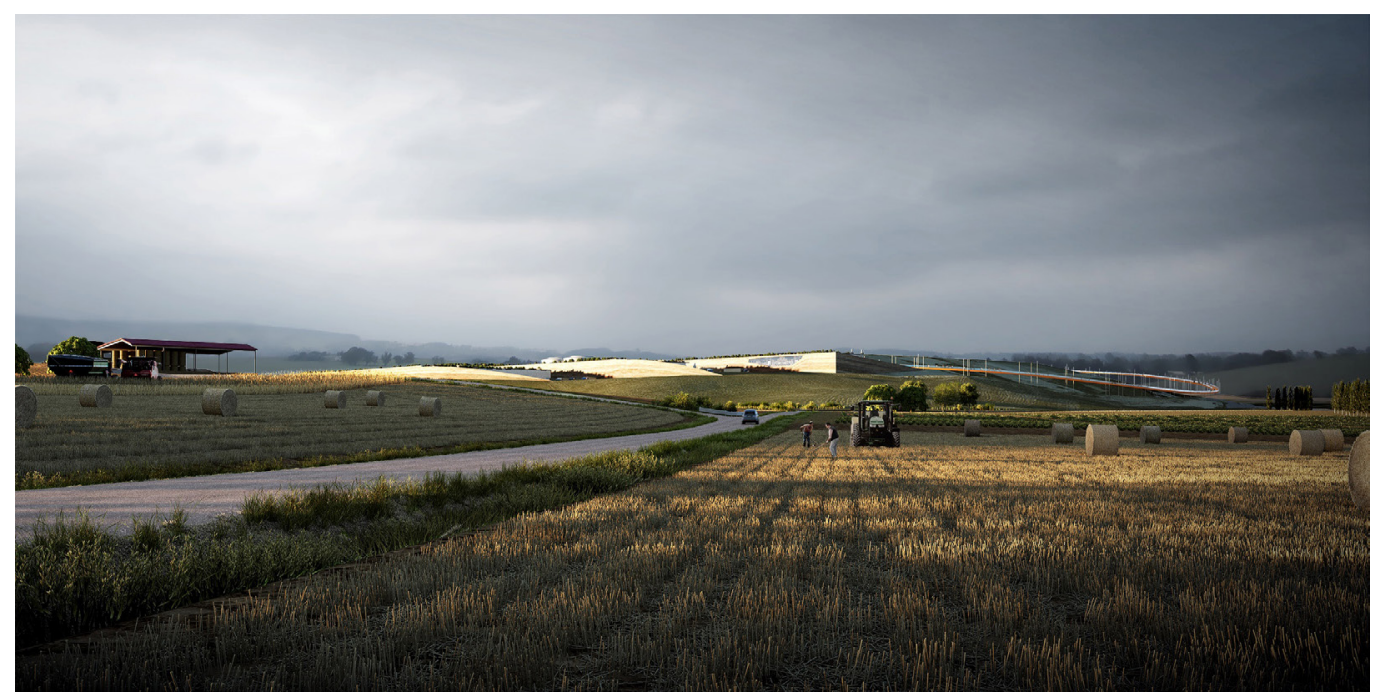


stante si semplifichino le elaborazioni richieste al rendering e si abbrevino in parte i tempi di sviluppo, il processo generativo dellimmagine mostra comunque una certa complessità nel momento della ricerca compositiva. Parti provenienti dal rendering vengono così unite a fondali fotografici o combinati in matte painting, per ottenere l'assetto più convincente rispetto al contesto naturale (fig. I). Le elaborazioni di questo tipo lasciano una grande libertà creativa al CG artist e ribadiscono il ruolo centrale della cultura visuale e della direzione artistica per determinare il valore comunicativo delle CGI.

Sono molti gli studi di visualizzazione che si contraddistinguono per l'uso della natural visualization, tra questi si possono individuare: Engram (fig. 2), Beauty and The Bit (fig. 3), Bloomimages (fig. 4), per citarne solo alcuni. In particolare, lo studio norvegese Mir può essere preso a riferimento per aver esposto sul proprio sito web una sorta di 'manifesto' della visualizzazione naturale. Nel breve testo (non più visibile online) venivano riportati i tratti essenziali che caratterizzano un'immagine naturale, tra questi si poteva leggere:

"Camera angle, lighting, colour, and composition are the key ingredients that together make up the foundation of an image. A poor foundation cannot be saved with flares, fog and effects. [...] The "unique" in our images is derived from actual qualities in design and location rather than applied effects" [MirWay] [5].

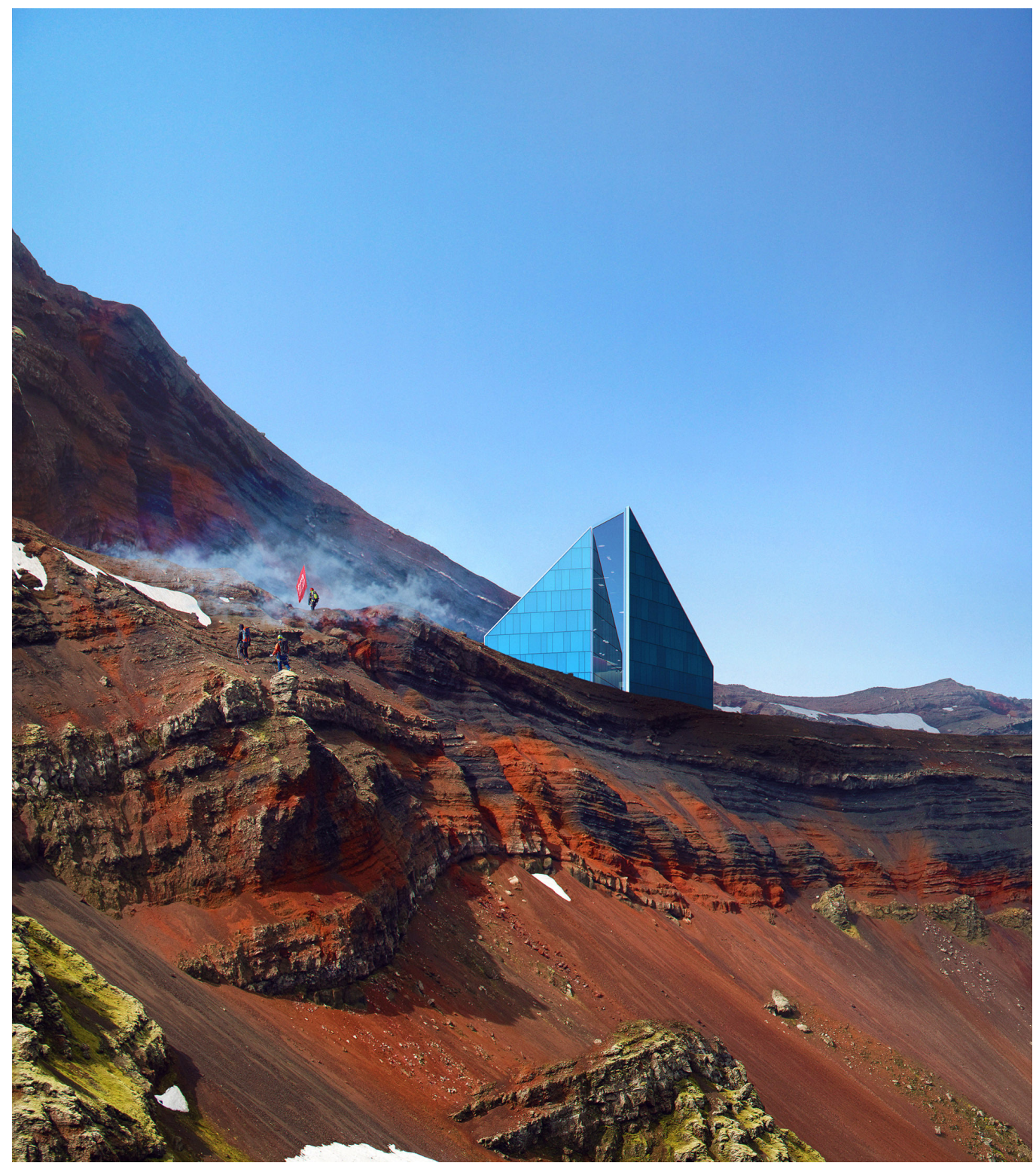


Da queste affermazioni si apprende come una luce innaturale e fortemente artefatta "can backfire and result in images that feel 'disgustive' and unnatural"' [Mir Way] [6]. Altro aspetto che viene tenuto in considerazione è quello del coinvolgimento emotivo dell'osservatore. Nelle immagini di Mir, il rapporto tra contesto naturale e antropico vede la netta superiorità del primo sul secondo (fig. 5). Spesso gli edifici rappresentati sono interamente immersi nella nebbia e si rivelano per una piccola porzione visibile. Questo tipo di rappresentazione rimanda al sentimento del Sublime, espresso nel pensiero estetico del filosofo Immanuel Kant, per cui l'uomo si misura con lo spettacolo della natura e con le immagini dei luoghi. II sentimento del Sublime è stato originato dalla lunga riflessione della cultura europea nell'arco dell'Ottocento e sembra rivivere oggi una seconda stagione all'interno delle più

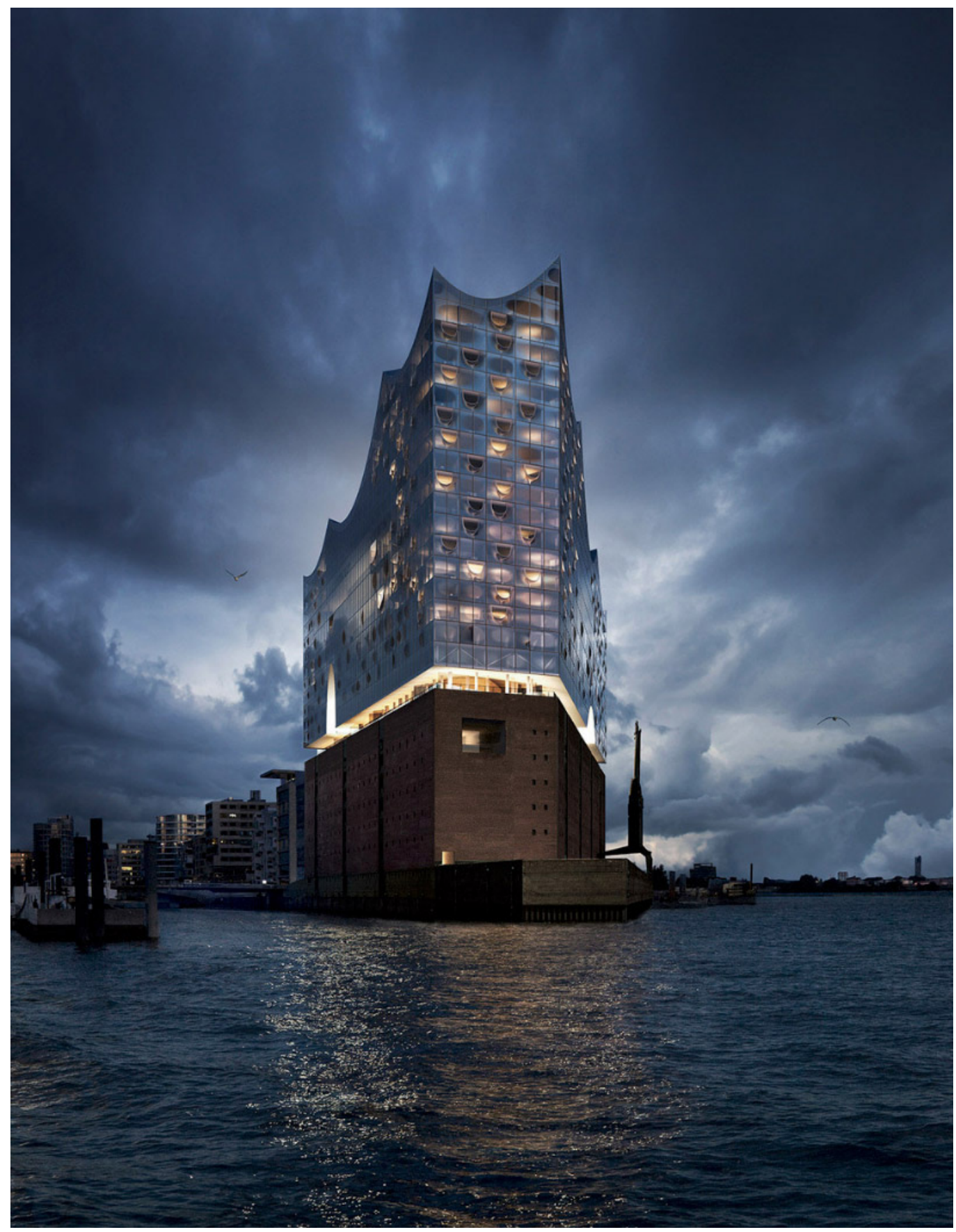


Fig. 5. Mir, lcefjord Centre di Dorte Mandrup

Arkitekter, Icefiord (Groenlandia), 2016.

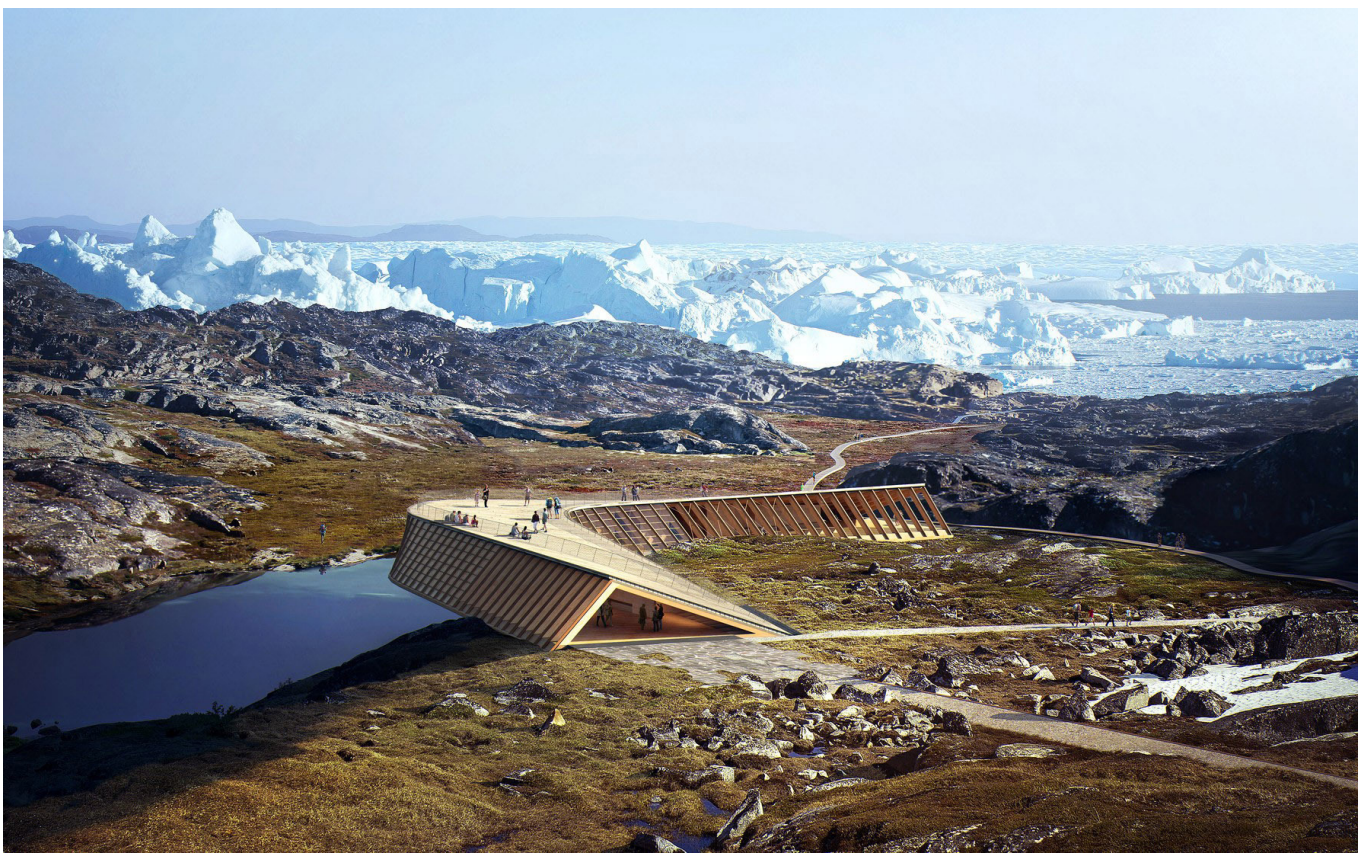

recenti immagini della computer grafica. Nella Critica del giudizio [7] il filosofo tedesco si riferiva al 'sublime dinamico' per descrivere il naturale piacere che deriva dalla visione di scenari minacciosi "permettendo di rintracciare la somiglianza tra esperienze simboliche, come quelle vissute nella contemplazione di uno spettacolo naturale, ed esperienze di vita estreme, come quelle della guerra" [De Luise 2010, p. 234]. Paesaggi impervi, ripide scogliere, vegetazioni intricate, nebbia e foschia, cieli plumbei che esasperano la drammaticità dell'immagine, sono elementi ampiamente condivisi dall'attuale linguaggio visivo della comu-

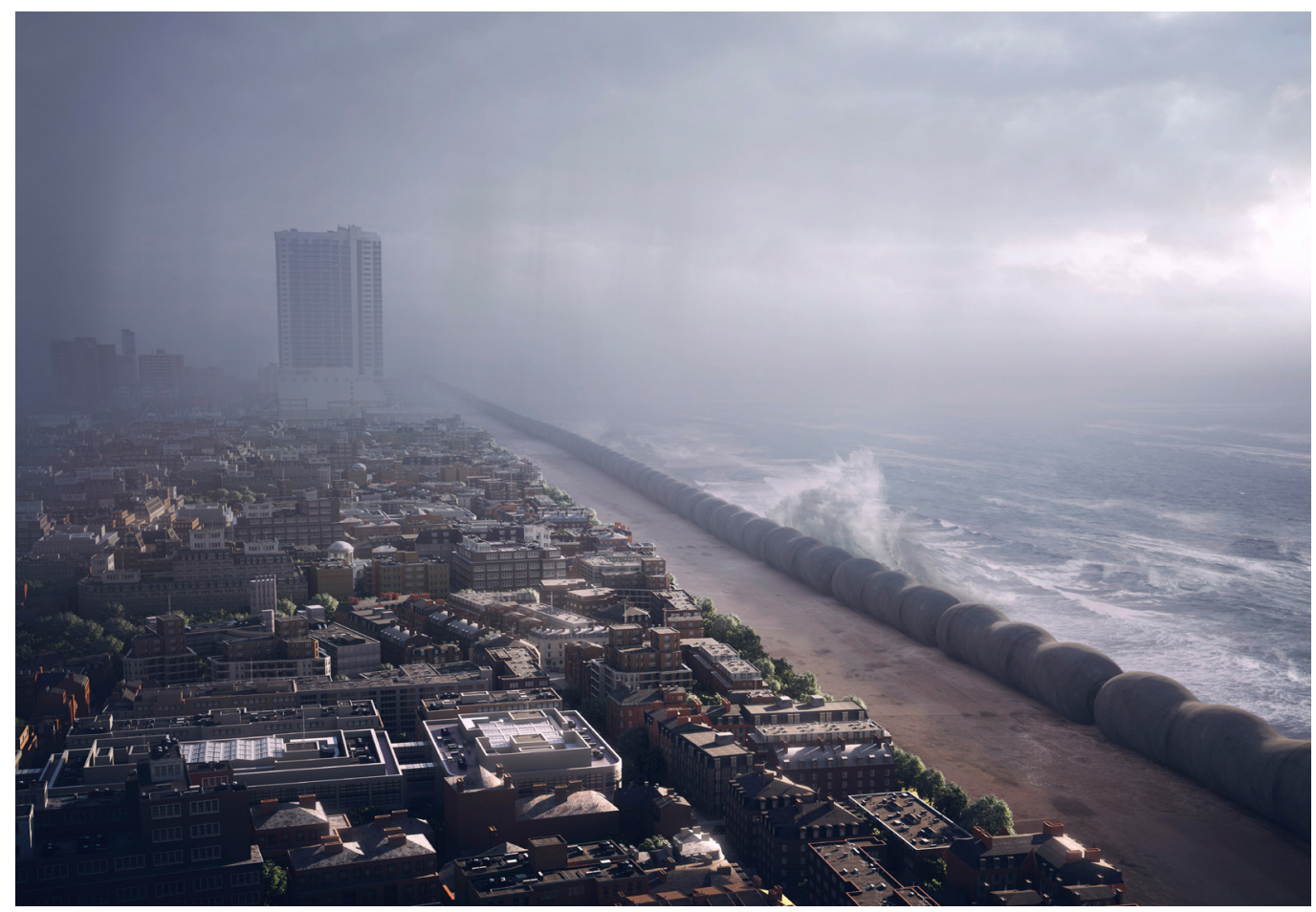


nicazione architettonica e, più in generale, trasposti dalla cinematografia degli ultimi anni (fig. 6). In questo scenario, dove le possibilità creative sono completamente demandate alle fasi di compositing digitale, la presenza della vegetazione è divenuta un elemento centrale per la resa espressiva dei progetti architettonici. A rinvigorire la tendenza è il legame tra le agenzie di visualizzazione e i landscape designer, spesso chiamati a intervenire insieme nelle prime fasi di ideazione del progetto. Infine, si può rilevare come ad adottare il linguaggio della natural visualization siano state - e continuano tutt'ora a essere - le principali compagnie attive nell'archviz, le quali implementano sempre nuove soluzioni per approcciare la rappresentazione del paesaggio (fig. 7). Sia che si tratti delle tecniche del compositing fotografico, del matte painting o di megascan (le più recenti campagne di acquisizione fotogrammetrica del paesaggio), il fenomeno della natural visualization può dirsi una vera costante nelle tendenze del rendering contemporaneo.

\section{Landmark, cinema e paesaggio}

Anche il parallelo tra cinema e archviz offre molti spunti di riflessione per ciò che riguarda la rappresentazione del paesaggio nelle simulazioni al computer. Si può constatare, infatti, sia come le referenze visive - ricorrenti nelle animazioni architettoniche e nei CG film provengano da un immaginario cinematografico e sia come le soluzioni di color grading - in comune nei vari software a disposizione del video editor - contribuiscano all'uniformità della resa cromatica nei media digitali. Questa convergenza, nell'estetica dell'immagine, è condivisa ormai da tutte le discipline che operano con le tecniche di elaborazione in post-produzione. Come afferma il teorico dei nuovi media Lev Manovich, la 'perfezione' estetica, attribuita all'immagine digitale, può essere considerata proprio a partire dai film e dalle animazioni pre-digitali e in particolare:

"This perfection of images in the twenty-first century is damaging the meaning and the value of cultural heritage. Sometimes I find it difficult to watch films from the 90 s simply because of their visual texture and because they don't have enough contrast when things are not colour-enhanced, and I'm supposed to be more of a sophisticated viewer, right? Maybe I'm just paying too much

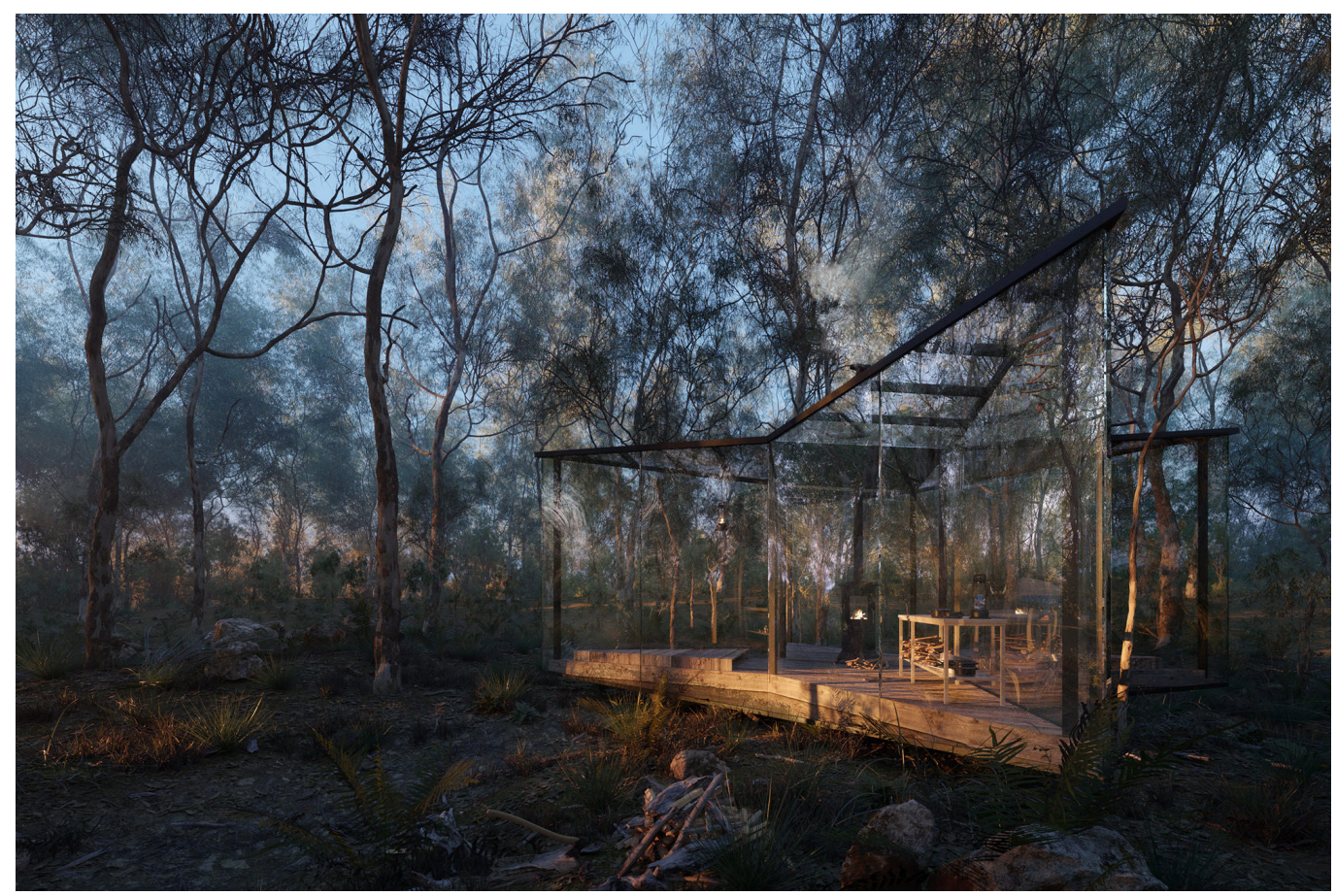


attention, and everything I watch today is perfect, so things that haven't been perfected are going to stand out" [Honeyball 20I5, p. 27I].

Nonostante il divario tra i mezzi tecnici impiegati, le animazioni al computer si riferiscono con frequenza alle soluzioni e alle strategie messe a punto dal cinema tradizionale, soprattutto in fatto di regia e storytelling. È questo il caso di Landmark (20 I 8), lo short film, diretto e ideato da Victor Bonafonte e realizzato da Beauty and The Bit, in cui vengono introdotti sia uno storytelling dal carattere cinematografico (fig. 8) e sia piani sequenza e inquadrature che si avvalgono - nel loro sviluppo spaziale - della piena libertà di movimento delle virtual camera. La fiaba architettonica - come riporta il sottotitolo dell'animazione - nasce con l'intenzione di sperimentare nuove forme di linguaggio nel racconto dell'architettura. Landmark, viene presentato con la descrizione che segue:

Fig. 8. Fotogramma tratto da Landmark, Short film

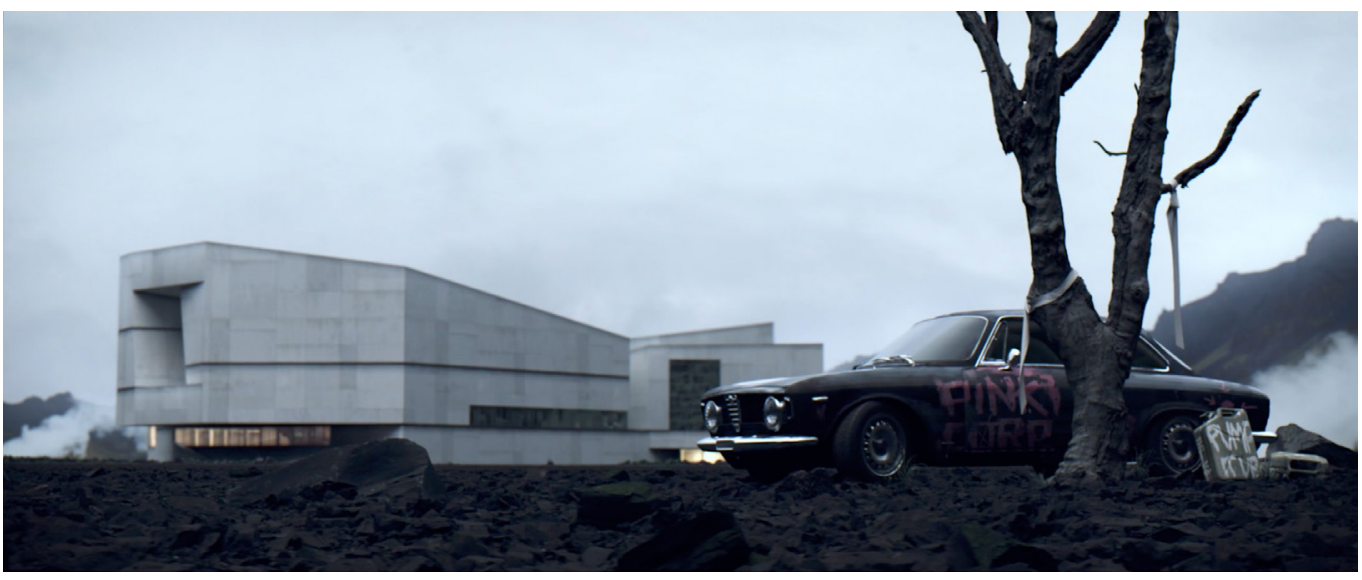

"It is a project made with the intention of exploring other languages in architectural animation. It is our attempt to add emotional content, strong storytelling and art direction to it. We have tried to achieve a cinematographic experience to show that a solid narrative is not at odds with architecture films. Landmark is not an architecture animation but an architecture movie" [8] [Beauty and The Bit 2018].

Nel raccontare le fasi di sviluppo del progetto visivo, Victor Bonafonte ribadisce l'estrema importanza del perseguire in architettura un linguaggio cinematografico, in questo caso ispirato da registi come Stanley Kubrick, Ridley Scott, Denis Villeneuve e più in generale della science fiction. Anche lo sviluppo del progetto di animazione ha seguito le fasi canoniche di

Fig. 9. Fotogramma tratto da Landmark, Short film di Beauty and The Bit, 2018. L'edificio isolato è ambientato in un paesaggio liberamente ispirato alla natura islandese.

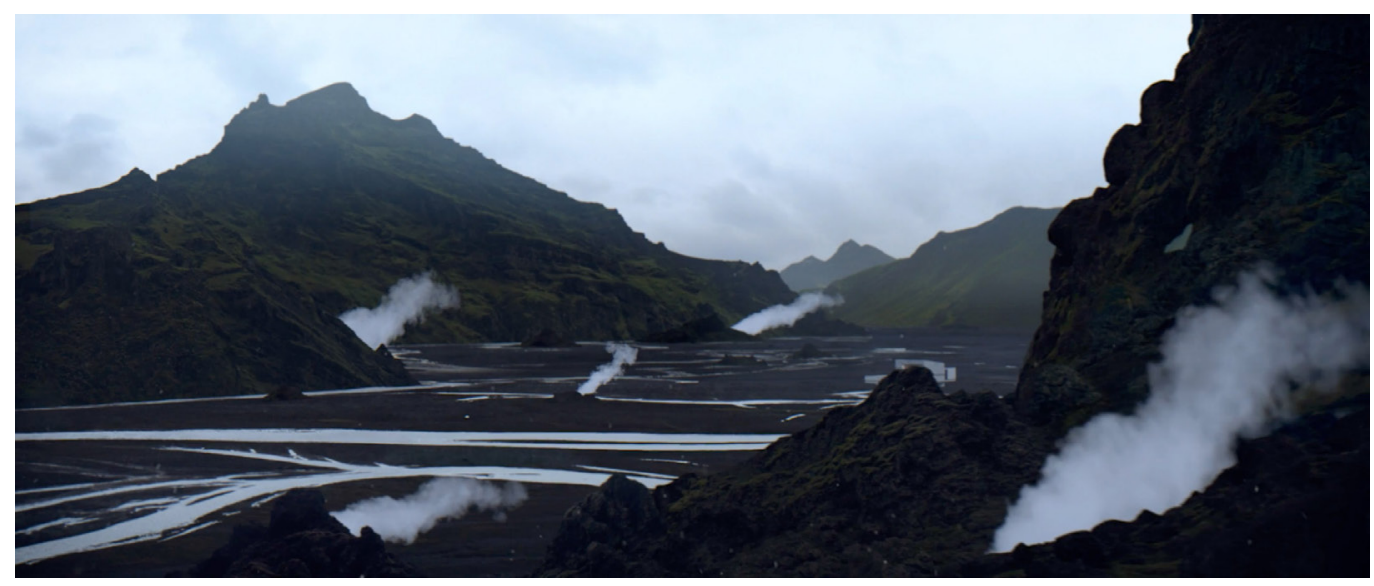


Fig. 10. Beauty and The Bit, Landmark, 2018. In alto: la vista semplificata del modello impirat del modello implegata duzione per studia-proprincipali piani sequenza. principali piani sequenza. In basso: un fotogramma del film con il renderin della scena provvisto di texture, $3 d$ assets e post-produzione.
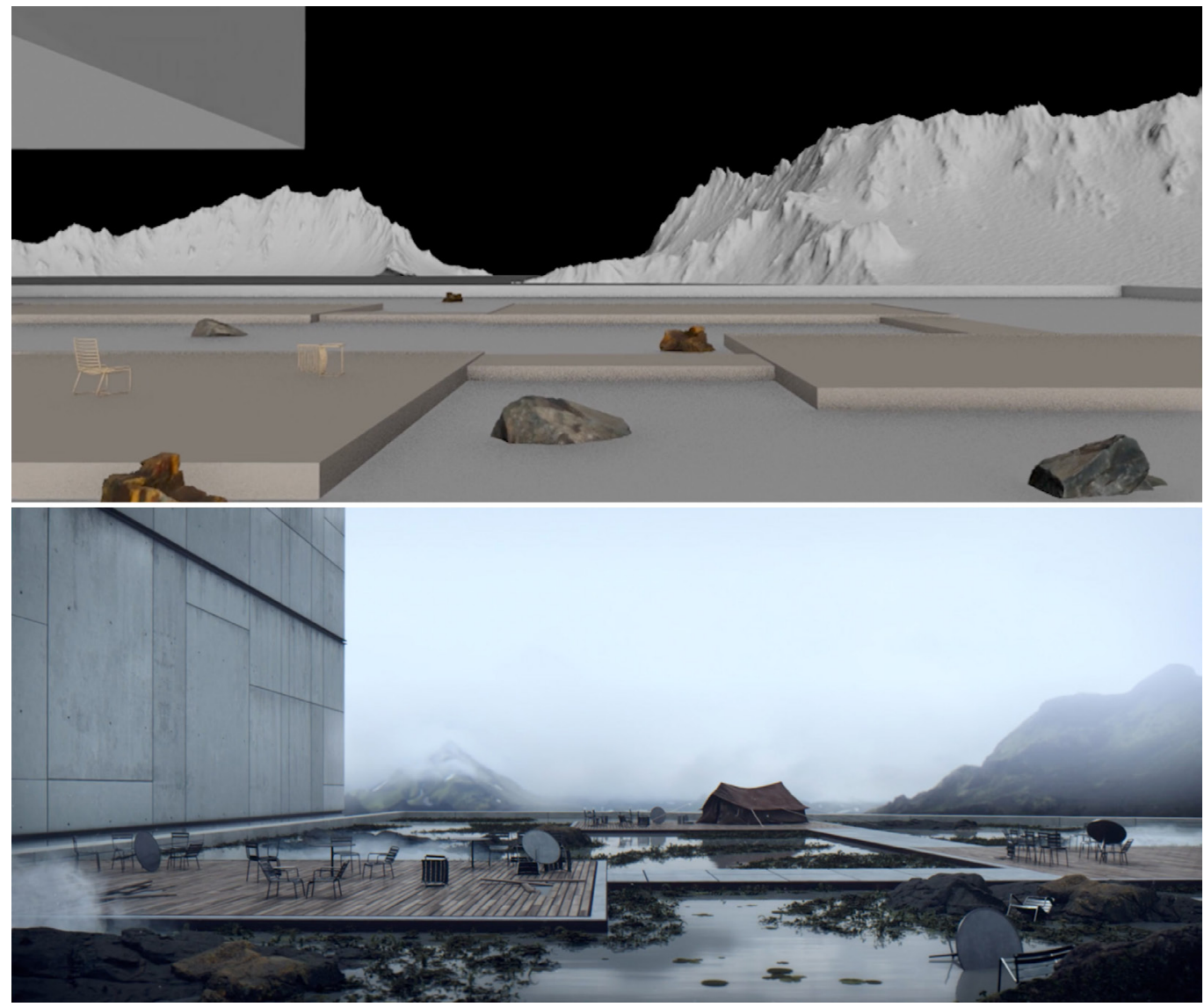

una produzione cinematografica. Dalla sceneggiatura emerge il soggetto del racconto: un tecnico informatico al lavoro per un mega server in un edificio isolato nel nulla. L'edificio d'invenzione è ambientato in un paesaggio nordico (fig. 9) ispirato all'Islanda. La fase di pre-produzione (pre-viz) ha visto l'impiego dei modelli 3D, sia del paesaggio che dell'edificio, entrambi animati e visualizzati a schermo nelle modalità di shading più semplici come gouraud o hidden line (fig. I0). Nella fase di produzione, invece, lo studio spagnolo ha indagato le forme dell'edificio principale, concepito e progettato proprio in relazione allo storytelling [9]. I numerosi modelli di studio 3D, visualizzati sia tramite rapidi clay-render (fig. I I) che nel loro inserimento nel paesaggio, si può dire che rappresentino la parte più interessante dello sviluppo del film. Qui vengono esposte tutte le possibilità che il modello informatico dimostra di avere quando è unito allo sviluppo visuale del progetto di architettura. In Landmark (fig. I2), infatti, è stato fatto uso della direzione artistica e dello storytelling per orientare al meglio la resa dell'architettura nel suo racconto animato. Lo stesso Bonafonte afferma come "un'immagine senza direzione artistica sia impersonale, è un qualcosa che chiunque altro avrebbe potuto fare" [Beauty and The Bit 20 17]. Della stessa idea è anche Jeff Mottle, CEO di CGarchitect e parere autorevole nell'archviz, il quale afferma come nel corso degli ultimi vent'anni gli avanzamenti e i nuovi strumenti tecnologici, resi di più facile utilizzo, abbiano assunto un ruolo sempre più marginale nell'industria del 3D, mentre le capacità di emergere nel settore dipendano dal talento individuale del CG artist e dalla sua capacità di differenziarsi tramite un proprio linguaggio.

"That was the next major turning point in the industry. That's when the people who also had a talent in lighting, photography, and storytelling started to distinguish themselves from the rest of the crowd. The companies that do the best work now are the ones that probably do at least $50 \%$ of their work in post. The work that they do is very cinematic in their treatment and the way they approach things. Those are the companies, for the most part, that are still around today. The 
Fig. I I. Beauty and The Bit, Landmark, 2018 . Un clay-render di studio volumetriche dell'edifico rispetto alle riprese del rispetto alle riprese de

Fig. I I. Beauty and The Bit, Landmark, 20 I8. Gli spazi interni mostrano il server dove soltanto un tecnico informatico gestisce il successful ones, the ones that survived the recession, are the ones that have been able to diversify themselves" [Feldman 20I3].

In questo scenario, il confronto diretto tra il cinema e le tecniche di post-produzione - queste ultime largamente impiegate nell'ambito dei CG film per l'architettura - non fa che dare riscontro dei profondi legami tra le arti visive e la visualizzazione architettonica.

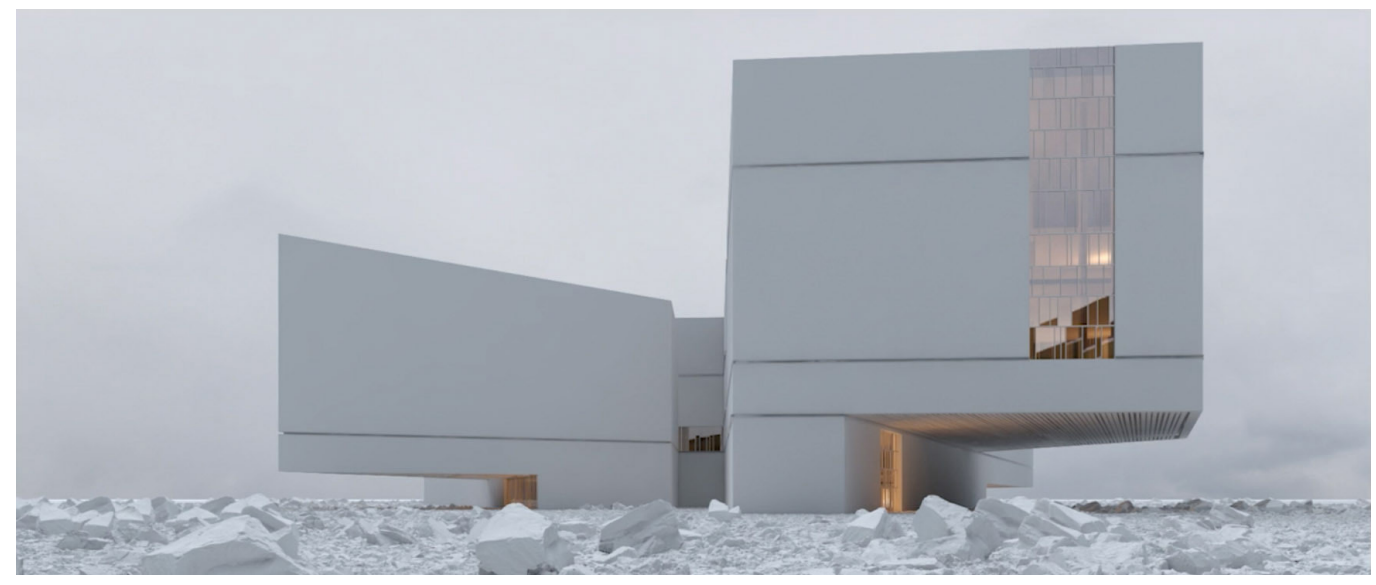

\section{Conclusioni}

Nella presente indagine si è voluto evidenziare come l'incisività delle recenti visualizzazioni 3D dipenda dal ritrovato legame tra il paesaggio e la sua nozione culturale e intellettuale nei confronti dell'architettura. A tale proposito, negli anni Duemila si assiste all'ascesa del fenomeno qui definito come natural visualization. Le immagini che rientrano in questa tipologia sono caratterizzate dal ricorso alle strategie visive della tradizione pittorica. Nelle illustrazioni di progetto prese in esame, ad esempio, si è individuato l'uso della pittura digitale, del photo compositing e del matte painting. L'unione di queste tecniche ha consentito di ampliare il registro espressivo della visualizzazione naturale, nella quale si possono rintracciare molte similitudini con il vedutismo settecentesco, la tradizione topografica inglese e il Romanticismo. In sostanza, è all'uso estatico del paesaggio che i visualizers ricorrono per sublimare la bellezza dei luoghi, ponendo in secondo piano l'architettura che diviene elemento residuale della composizione. Le parti provenienti dall'output di rendering vengono, via via, sempre più limitate, mentre spaziano le componenti atmosferiche che caratterizzano la drammaticità della scena rappresentata, prendendo spunto dal cinema e dalle arti visive. Il linguaggio della natural visualization continua tutt'ora a essere impiegato dalle principali compagnie attive nell'archviz, tanto da poter considerare il fenomeno tra le principali motivazioni della più generale tendenza all'omologazione e uniformità visiva del rendering contemporaneo.

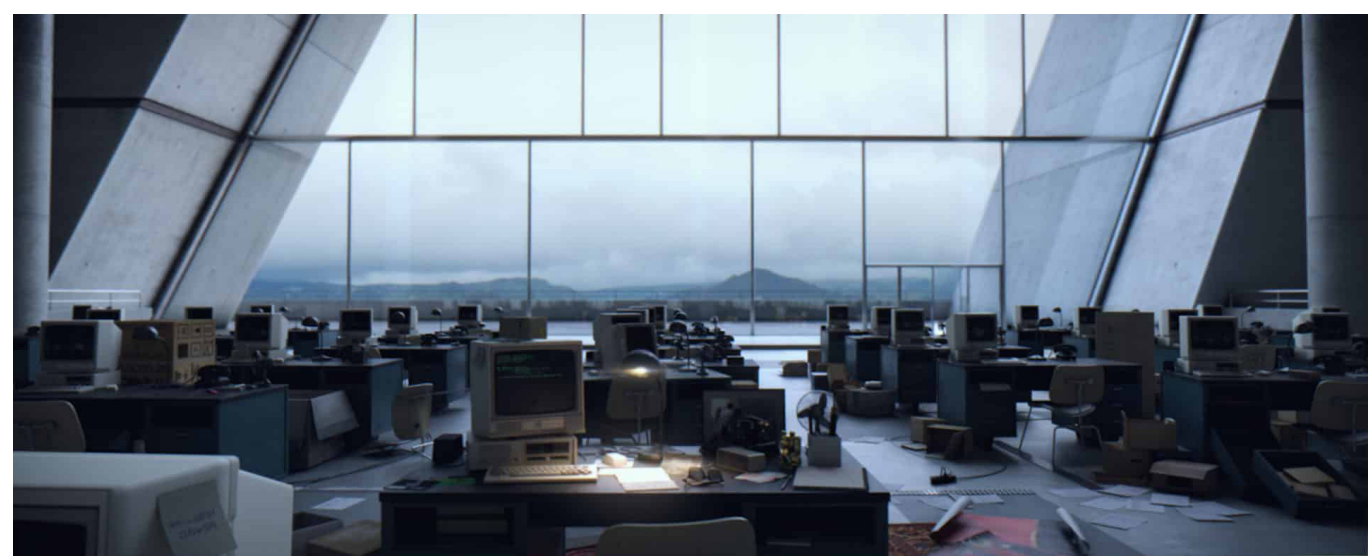




\section{Note}

[I]Vedi: Farinella 2019, pp. 33-45.

[2] Vedi: Haroz, Kwan-Liu 2006.

[3] Farinella 2019, pp. 19-32.

[4] Melcher 2014.

[5] MirWay. In: Mir. https://www.mir.no/info/ (il breve testo descrittivo è stato in seguito sostituito dallo studio norvegese).

[6] MirWay. In: Mir. https://www.mir.no/info/ (il breve testo descrittivo è stato in seguito sostituito dallo studio norvegese).

[7] Immanuel Kant (1993). Critica del giudizio. Torino: Utet, pp. 234-238.

[8] Beauty and The Bit (20।8). Landmark: <https://vimeo.com/288|35384>.

[9] Beauty and The Bit (20।8). Landmark The Journey (Making of): <https://vimeo.com/288|40838>.

\section{Riferimenti bibliografici}

De Luise Fulvia, Giuseppe Farinetti (20।0). Lezioni di storia della filosofia. Bologna: Zanichelli.

Farinella Cristian (2019). L'immagine costruita. La formazione, il ruolo e le tecniche del CG artist nella visualizzazione architettonica. Tesi di dottorato presso il Dipartimento di Storia Disegno e Restauro dell'Architettura. Sapienza Università di Roma.

Feldman Stuart (20 I 3). Interview With Jeff Mottle Of CGarchitect.com. In ReviewStudio. Blog: <https://www.reviewstudio.com/ blog/interview-with-jeff-mottle-of-cgarchitect-com/>.

Haroz Steve, Kwan-Liu Ma K. (2006). Natural Visualizations. In EuroVis 2006. The Eurographics Association: <https://doi. org/l 0.2312/VisSym/EuroVis06/043-050>.

Honeyball Simon (20 I5). Special Effects: New Histories, Theories, Contexts. London: Palgrave (Kindle Edition).

Melcher Henry (2014). From fireworks to kayaks, step inside the well-produced world of renderings. In: The Architect's Newspaper: <https://archpaper.com/20 |4/07/from-fireworks-to-kayaks-step-inside-the-well-produced-world-of-renderings/>.

\section{Sitografia}

Beauty and the Bit, studio di visualizzazione di Madrid, fondato daVictor Bonafonte e Lina Garau: < https://www.beautyandthebit. com>.

Bloomimages, studio di visualizzazione fondato nel 2008 con sedi a Berlino e Amburgo (Germania) :<https:// www. bloomimages.de>.

Engram, studio di visualizzazione con sede a Faenza fondato da Paolo Zambrini, che opera nell'archviz dal 1990: <http://www. engram.it/album/architecture/>.

K2 Visual, studio di visualizzazione fondato da Andras Balogh con sede a Budapest (Ungheria): <http:// k2visual.com/\#>.

Landmark, CG film realizzato dallo studio di visualizzazione spagnolo Beauty and The Bit e pubblicato online nel 20 I 8: <https:// vimeo.com/288135384>.

Landmark The Journey (Making Of): <https://vimeo.com/288|40838>.

Megascans, libreria online della Quixel che contiene numerose scansioni di materiali, terreni, e vegetazione, basate sul modello PBR (physically based rendering): <https://quixel.com/megascans>.

Mir, studio di visualizzazione norvegese: <https://www.mir.no>.

\section{Autore}

Cristian Farinella, Sapienza Università di Roma, cristian.farinella@uniroma l.it

Per citare questo capitolo: Farinella Cristian (2020). L'esperienza del paesaggio nella natural visualization/Experience of Landscape in Natural Visualization. In Arena A., Arena M., Brandolino R.G., Colistra D., Ginex G., Mediati D., Nucifora S., Raffa P. (a cura di). Connettere. Un disegno per annodare e tessere. Atti del $42^{\circ}$ Convegno Internazionale dei Docenti delle Discipline della Rappresentazione/Connecting. Drawing for weaving relationships. Proceedings of the 42th International Conference of Representation Disciplines Teachers. Milano: FrancoAngeli, pp. 445-466. 


\title{
Experience of Landscape in Natural Visualization
}

\author{
Cristian Farinella
}

\section{Abstract}

From the year 2000, in architectural visualization (archviz), we are observing the spread of a trend known as natural visualization, in which the primary communication strategy lies in creating images and animations in computer graphics making use of the aestheticizing contribution of the landscape. As a result, many areas of the archviz industry have specialized in creating assets and solutions dedicated to rendering vegetation and 3D environment. The scanning campaigns by Quixel, with its megascans, are among the most adopted landscapes in CG films, using massive parts of the Icelandic island and Nordic landscapes. The symbolic and participatory link of the observer with nature represents the most evident case of sublimation of the landscape and return to romantic themes even if this language today is used by the CG artist, or architectural visualizer, rather than by the painter, or the perspectivist of the past. For this reason, this study wants to propose an analysis and a close comparison between the digital works realized through digital landscapes, and the pictorial works that, even if conceived in past ages, appear to be contemporary in the conception, in the communication strategies, and in the adopted compositional structure.

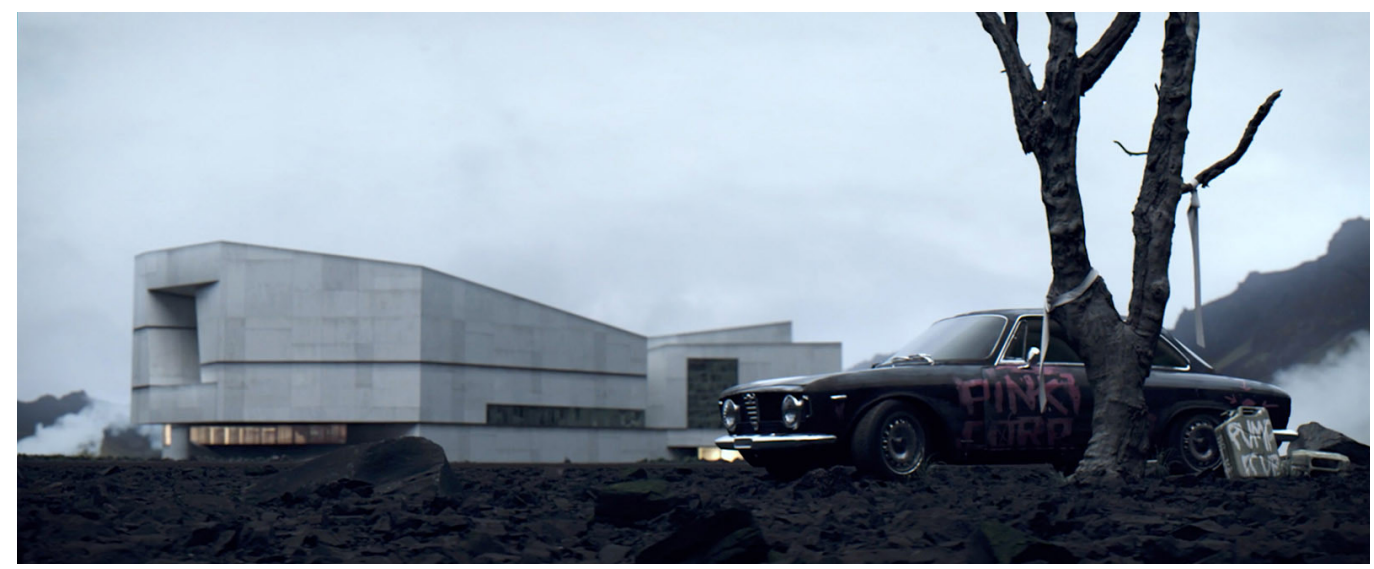




\section{Introduction}

Hand in hand with the widening of the expressive possibilities offered by information technology and digital imaging, the visualization trends in the architectural field seem to limit their interest to the dramatic atmospheres in use in the most consolidated cinematographic color corrections. Grey skies, marked contrasts, reduction of the chromatic range with a strong inclusion of blacks, reaffirm that cinema is still the medium with the most following in the architectural field. The 3D artists let themselves be inspired not only by the chromatic harmonies of cinema but also by their figurative language, to end up tracking down and even replicating the technical components, the shooting mechanisms, the camera movements, the lighting of the scene; all this without incurring the physical limitations present in the real world. The artificial nature that visualization uses in its computer images is shown as an aesthetic comparison with the perceived reality of the observer. The natural visualization is a trend that, since the 2000s, has exacerbated the change in scale between the anthropic and natural context, to follow much of the picturesque and romantic imagination of traditional art. In particular, the 3D artist makes explicit reference to eighteenth-century landscape painting, to the English topographic current, to the most famous romantic painters, to trace and re-present, with new interpretative models, the wealth of visual solutions of the artistic tradition from the past.

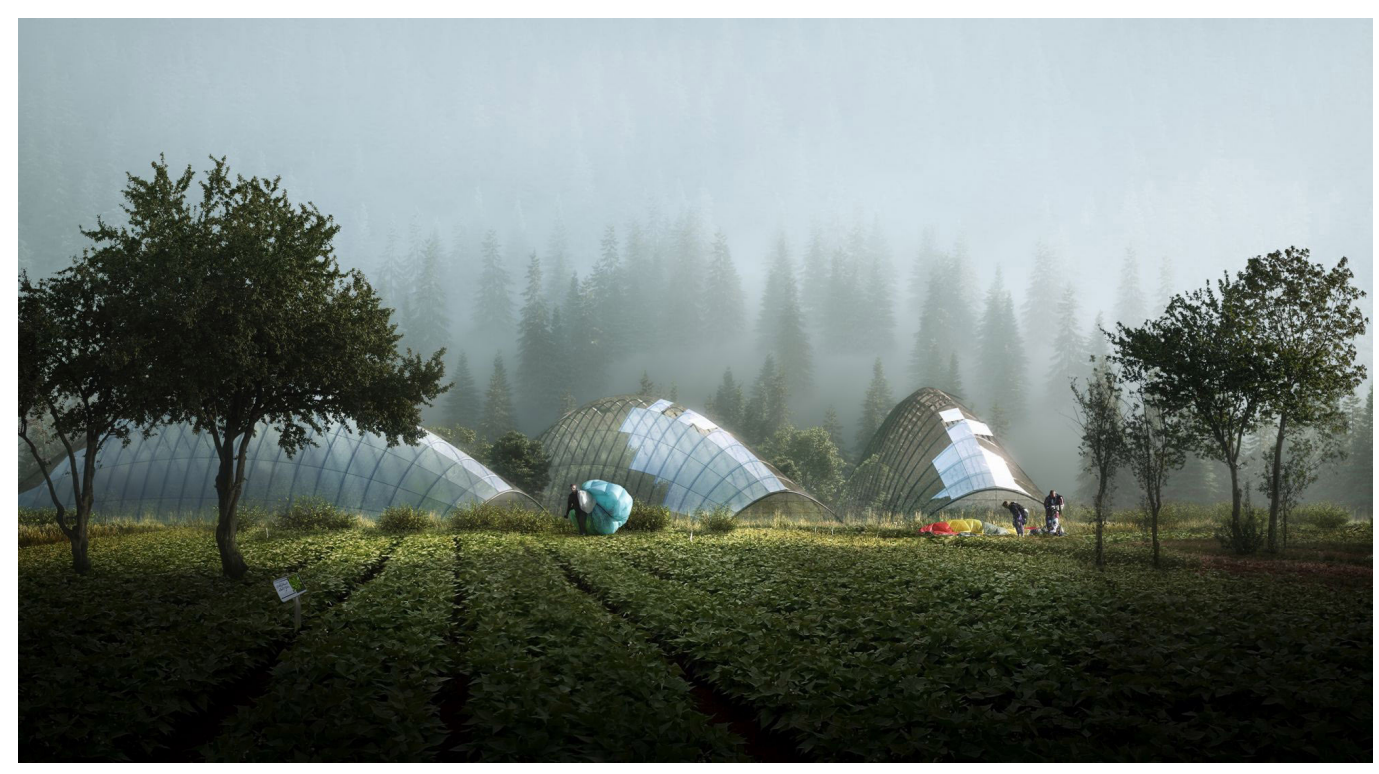

\section{The landscape of the natural visualization}

Without dwelling on the history of architectural perspectivist, and its cultural links with the pictorial tradition -whose argumentation is postponed in the bibliography [I]-, the term natural visualization, only recently adopted in archviz (an acronym for architectural visualization), has long been employed in the computer science and digital imaging, to describe the naturalness of an image by virtue of its spatial frequency. The measurement relates, through Fourier transformations, the variation of the intensity along a distance. In the visualizations is defined as natural the brightness value represented in diagram form, whose regular trend denotes the visual naturalness of the image. In the survey conducted by computer scientists $\mathrm{Haroz}$ and $\mathrm{Ma}$ [2], in which some representative images were examined, only those whose course on the spatial frequency graph was found to be regular were defined as "natural". Consequently, the pictures of animals, forests, mountains, or the sea appear natural; on the 
contrary, all graphic patterns and disturbances appear unnatural. If a rigorous notion of what can be considered natural in images may seem superfluous -or redundant-, we must not forget that the first computer-generated images were characterized by a wide use of graphic patterns, wireframe visualizations and artifacts, while it is only starting since the 2000s, the first experiences of natural visualizations in architectural rendering have been recorded. The latter is characterized by the rejection of clichés and stereotyped solutions in use in the nineties [3] which focused on a very pronounced color correction and an extended dynamic range. The purpose of the compositing technique distinguishes both the new natural approach and the previous graphic-illustrative approach, however, in the language of natural visualization at least two peculiar aspects can be identified: the ecstatic presence of nature, and a storytelling related to the subjects put into the scene.

The first aspect concerns the visualizations that resort to an ecstatic-contemplative use of the landscape, attributable to the pictorial works of nineteenth-century Romanticism, an artistic movement that has contributed, more than any other, to the formation of an aesthetic reference imaginary for the representation of nature and its connotations. The second peculiar aspect of natural visualization is, instead, the one related to storytelling. In the archviz, the term refers to the art of telling stories through images, an expression used in a recurring way on the websites of the agencies that deal with visualization. The use of visual storytelling is therefore used as a veritable strategy of persuasive communication of the architectures represented. In this case, the natural character given to the settings is also suggested by the actions performed by the subjects depicted, that is, by situations in which there are no particular strains and oddities.

To understand this new paradigm, just think of rich architectural renderings instead of real memes. Alcuni sono divenuti così famosi da aver dato vita a pagine e gruppi di discussione online. Some have become so famous that they have created pages and discussion groups online. In the 2000s, kayakers (the typical Inuit canoe) were the alienating element to be recurrent in the views of many projects, as in the case of the Golden State Warriors Arena (20I2) by Snøhetta and AECOM in San Francisco, and in the Salling Tower (20I3) by Dorte Mandrup Arkitekter in Denmark [4]. Equally numerous, in architecture competitions, were the images that showed a wide range of flying objects, including meteorological probes, and balloons. Natural visualization, therefore, represents a radical change in the process of image development, not only in aesthetic purposes but also in the practical and operational aspects of rendering development. During the typical workflow of a natural visualization, the rendered parts are less employed and replaced by photographs and digital paintings. Although the extensive use of bidimensional elements shortened the time, the composition is a crucial element during the image-making to not be undervalued. Small parts coming from

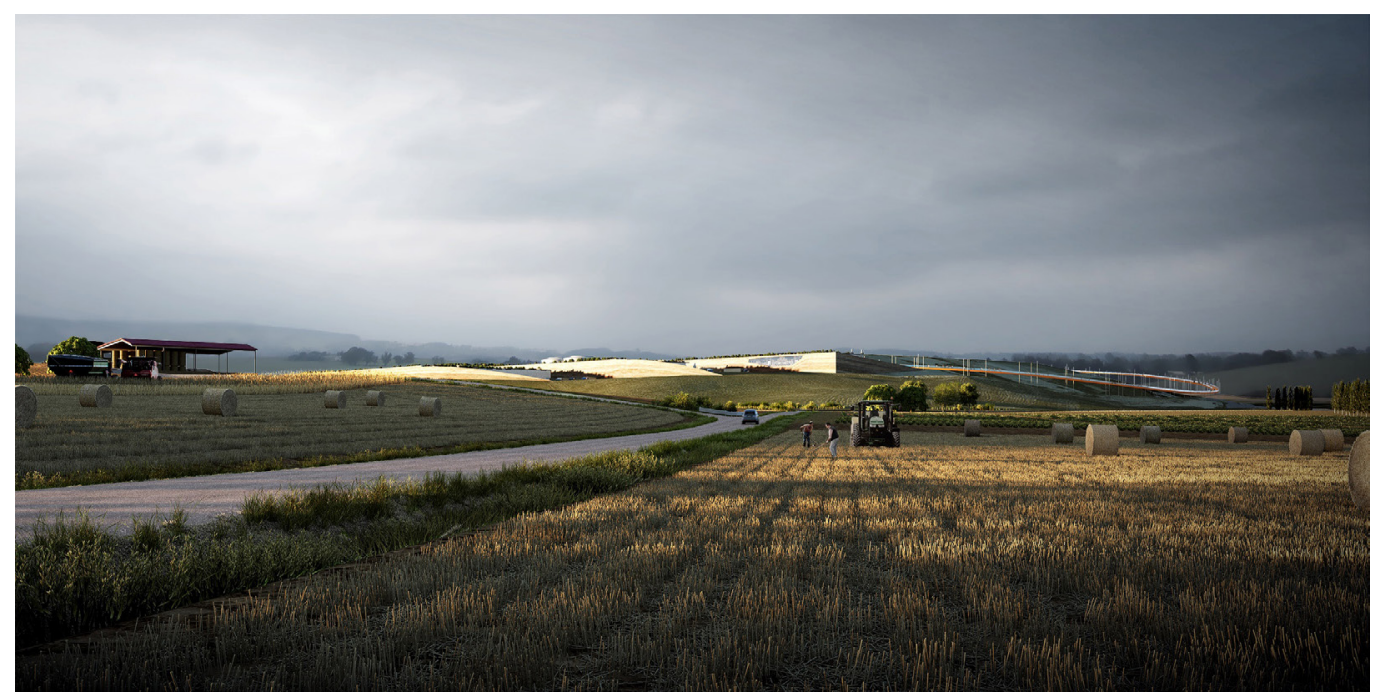


the rendering are thus combined with photos or combined in matte painting, to obtain the most convincing structure for the natural context (fig. I). This type of graphic elaboration leaves great creative freedom to the CG artist and reaffirm the central role of visual culture and artistic direction to determine the communicative value of the CGI.

Many visualization studies are characterized by the use of natural visualization, among these we can identify: Engram (fig. 2), Beauty and The Bit (fig. 3), Bloomimages (fig. 4), K2 Visual (fig. I), to name just a few. In particular, the Norwegian Mir study can be taken as a reference for having displayed a kind of natural visualization manifesto on its website. In the short text (no longer visible online) were reported the essential traits that characterize a natural image, among these, we could read: "Camera angle, lighting, colour, and composition are the key ingredients that together make up the foundation of an image. A poor foundation cannot be saved with flares, fog and effects. [...] The "unique" in our images is derived from actual qualities in design and location rather than applied effects" [5].

From these statement we learn how an unnatural and strong artificial light "can backfire and result in images that feel 'disgustive' and unnatural" [6]. Another aspect that is taken into consideration is the emotional involvement of the observer. In Mir's images, the relationship

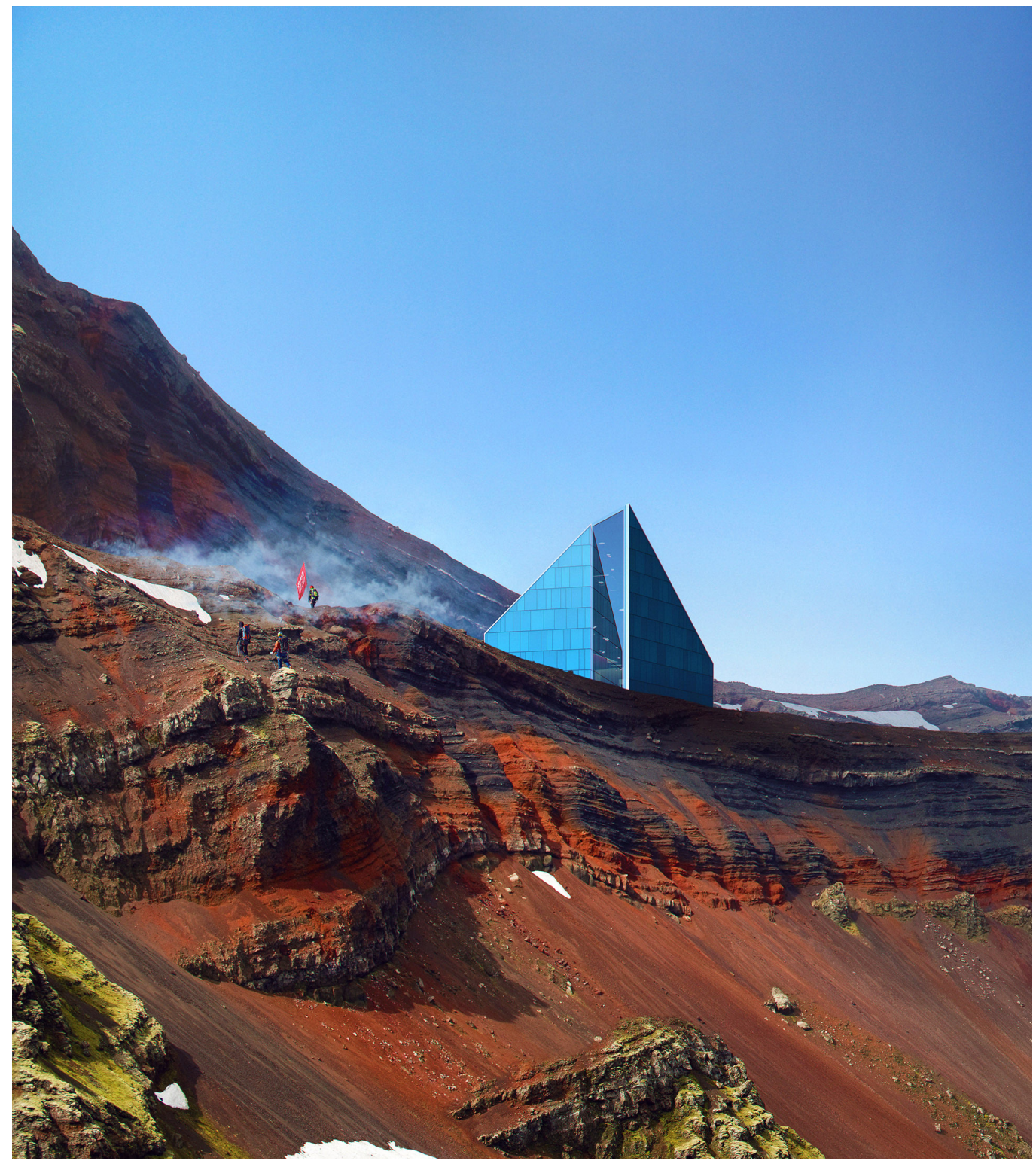


between natural and anthropic context sees the clear superiority of the former over the latter (fig. 5). Often the buildings represented are entirely immersed in the fog and are revealed by a small portion of the visible. This type of representation refers to the feeling of the Sublime, expressed in the aesthetic thought of the philosopher Immanuel Kant. In his thesis, man is measured by the spectacle of nature and the images of places. The feeling of the Sublime was originated by the long reflection of European culture during the nineteenth century and today seems to relive a second season within the most recent images of computer graphics. In the Critique of Judgment [7] the German philosopher referred to the dynamic sublime to describe the natural pleasure that derives from the vision of threatening scenarios "allowing to trace the similarity between symbolic experiences, such as

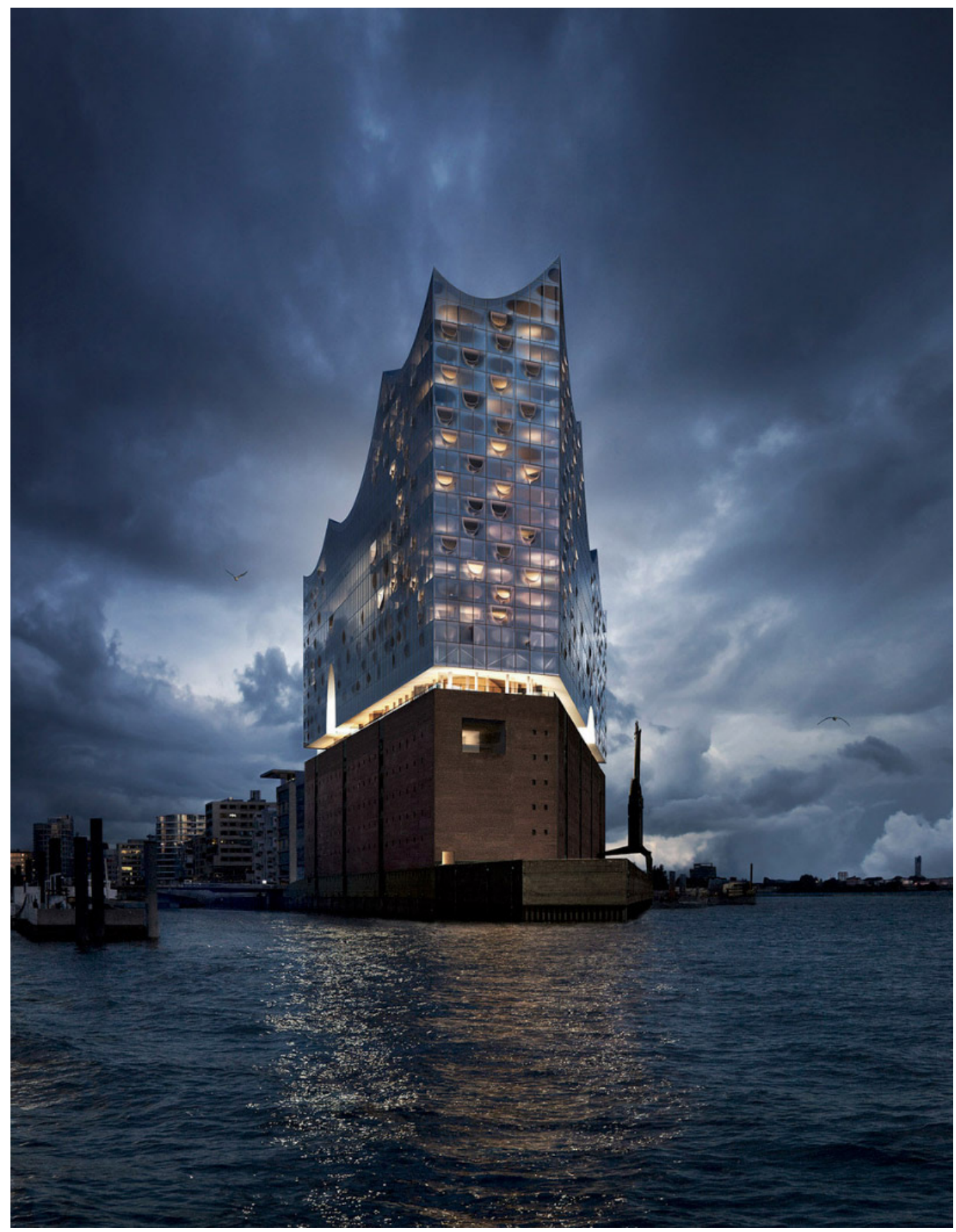




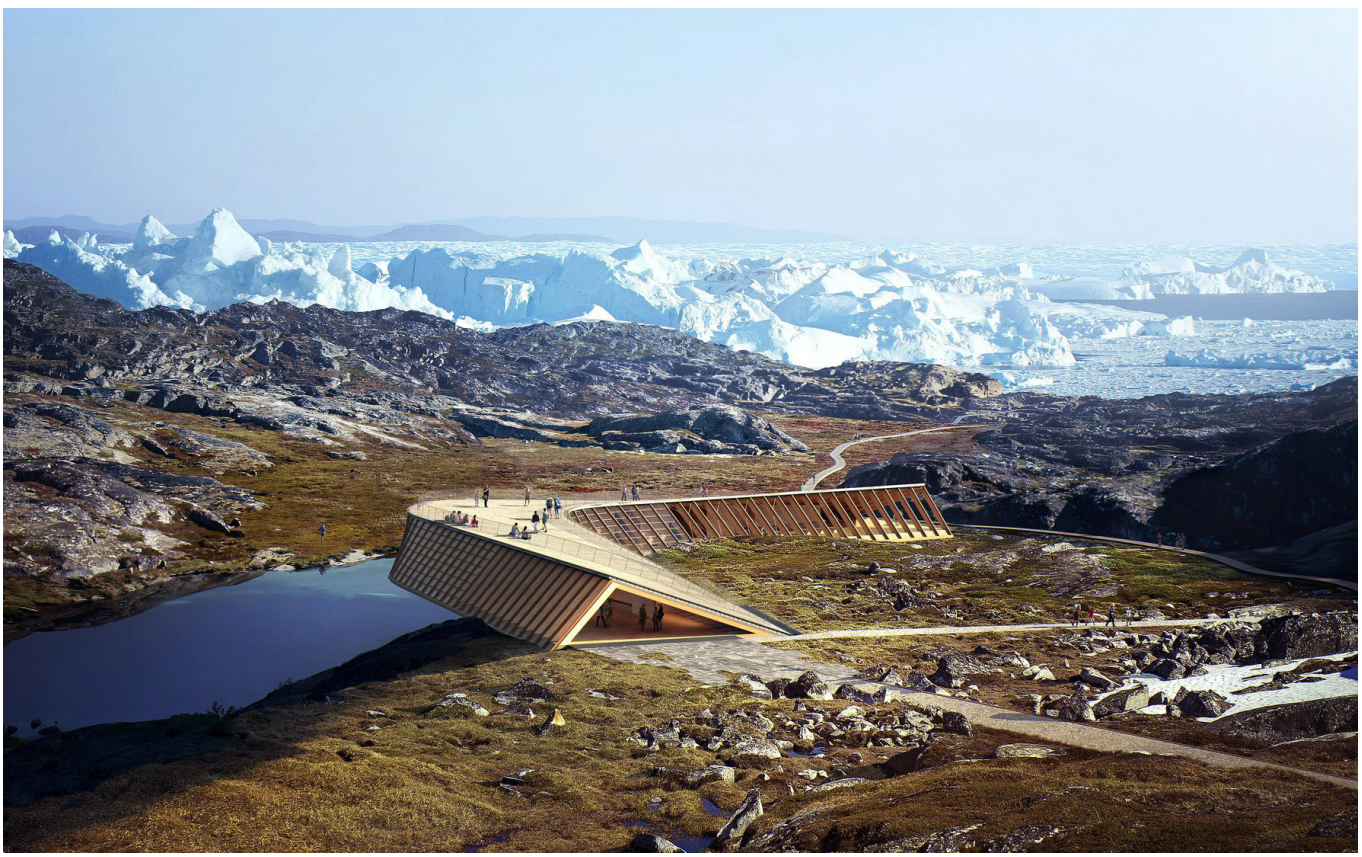

those experienced in contemplation of a natural spectacle, and life experiences extreme, like those of war" [De Luise 20I0, p. 234]. Rough landscapes, cliffs, intricate vegetation, fog and mist, leaden skies that exacerbate the drama of the image, are elements widely shared by the current visual language of architectural communication and, more generally, transposed by the cinematography in recent years (fig. 6). In this scenario, where the creative possibilities are entirely left to the digital compositing phases, the presence of vegetation has become a central element for the rendering of architectural projects. To reinforce the

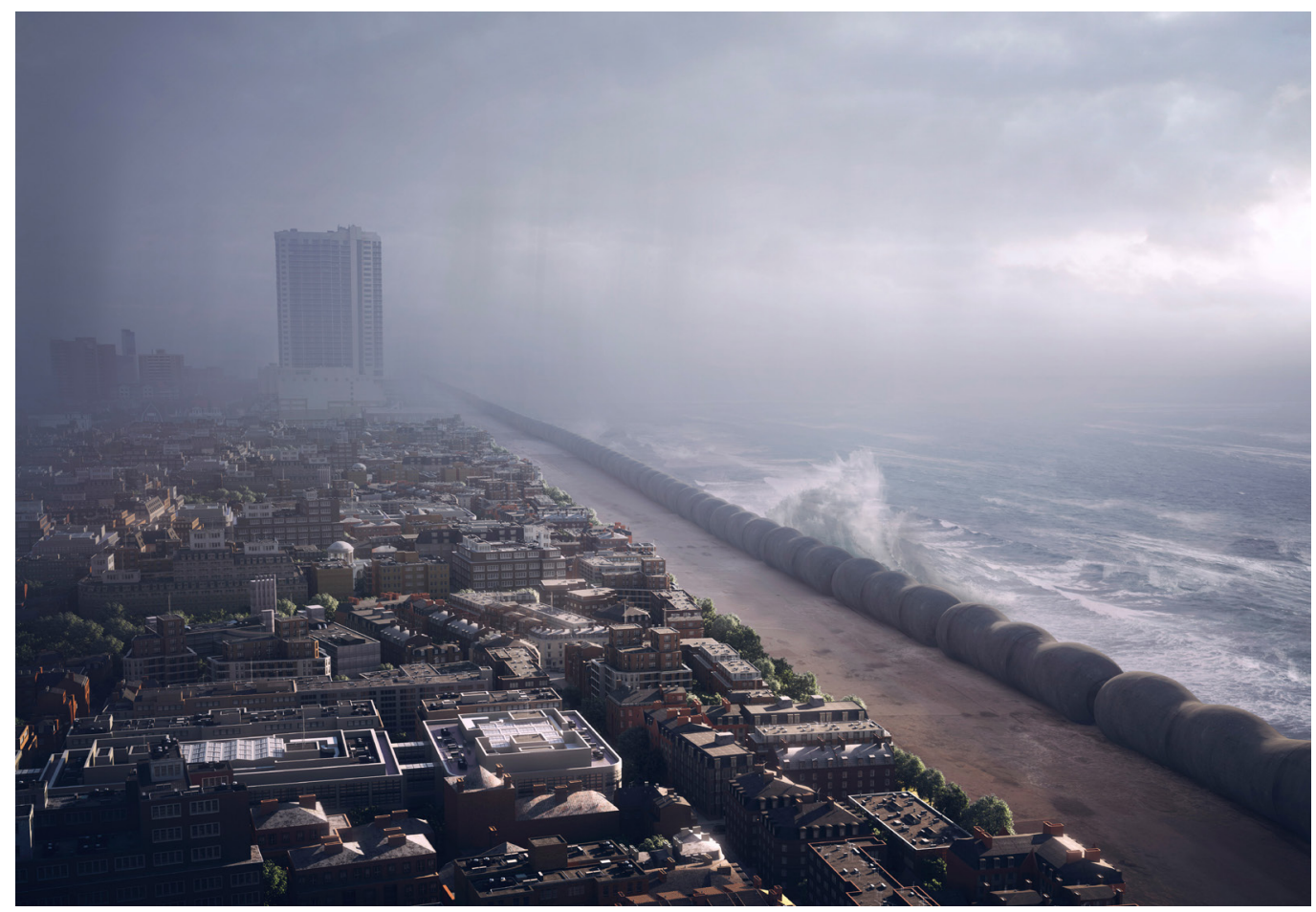


trend is the link between the visualization agencies and the landscape designers, often called to intervene together in the early stages of project design. Finally, it can be seen how the leading companies active in the archviz have adopted the language of natural visualization, which always implement new solutions to approach the representation of the landscape (fig. 7). Whether it is the techniques of photographic compositing, matte painting or megascans (the most recent photogrammetric landscape acquisition campaigns), the phenomenon of natural visualization can be considered a true constant in contemporary rendering trends.

\section{Landmark, storytelling and landscape}

Even the parallel between cinema and archviz offers many points of reflection as regards the landscape in computer simulations. It can be seen, in fact, as the visual references -recurrent in the architectural animations and CG films- come from a cinematographic imaginary and like the color grading solutions -in common with video editing software-contribute to uniformity of color rendering in digital media. This convergence, in the aesthetics of the image, is now shared by all the disciplines that work with post-production processing techniques. As stated by the new media theorist Lev Manovich, the aesthetic 'perfection' attributed to the digital image can be considered starting from films and pre-digital animations and in particular: "This perfection of images in the twenty-first century is damaging the meaning and the value of cultural heritage. Sometimes I find it difficult to watch films from the $90 \mathrm{~s}$ simply because of their visual texture and because they don't have enough contrast when things are not colour-enhanced, and I'm supposed to be more of a sophisticated viewer, right? Maybe l'm just paying too much attention, and everything I watch today is perfect, so things that haven't been perfected are going to stand out" [Honeyball 20 I 5, p. 27I].

Despite the gap between the technical means used, computer animations often refer to the solutions and strategies developed by traditional cinema, especially in terms of direction and storytelling. This is the case of Landmark (2018), the short film, directed by Victor Bonafonte and created by Beauty and The Bit, which introduces cinematographic storytelling (fig. 8) with sequence and framing that use free camera movements made possible by the

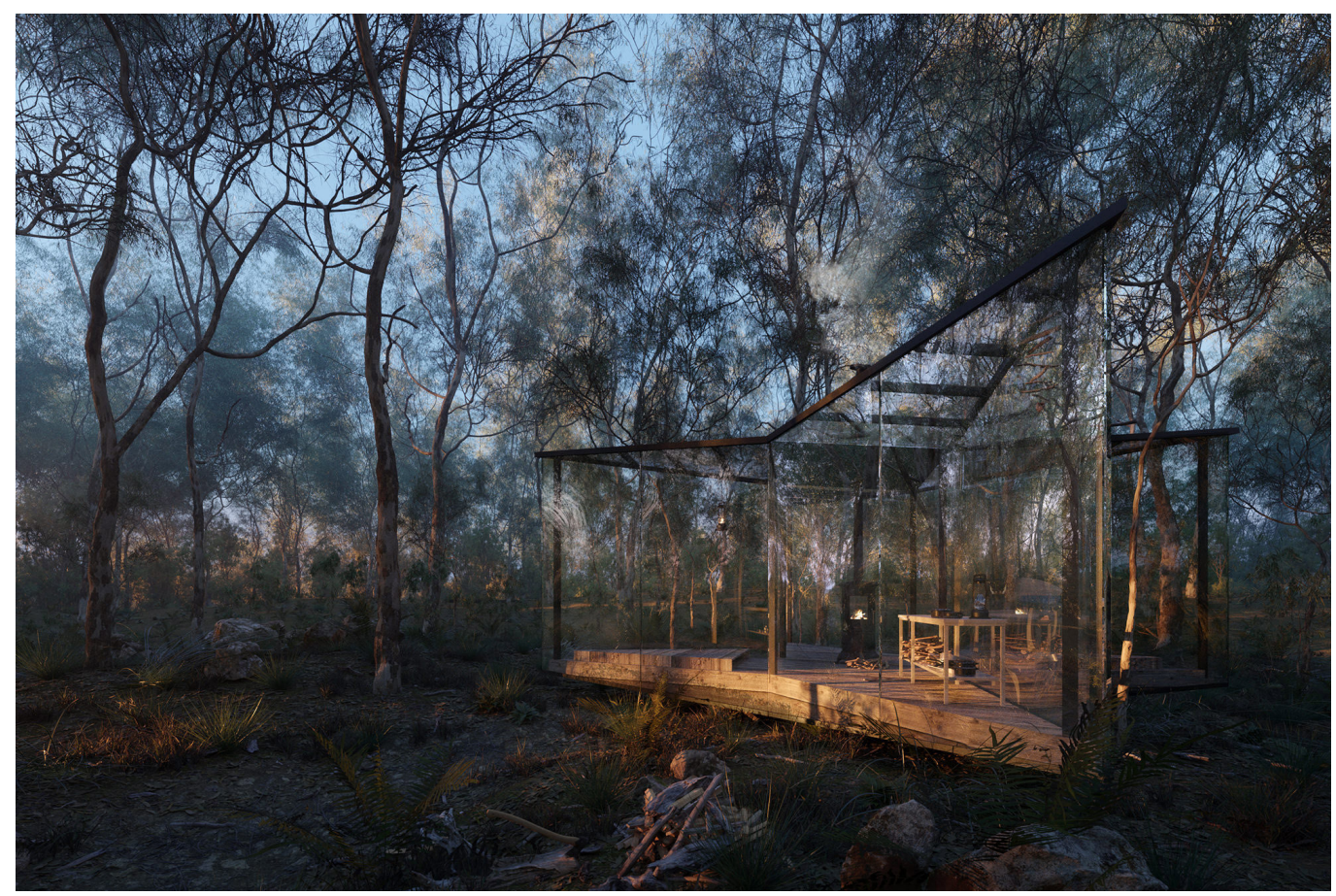


virtual set. The architectural fable- as reported in the subtitle of the animation -was born to experiment with new forms of language in architecture. Landmark, is presented with the following description: "It is a project made with the intention of exploring other languages in architectural animation. It is our attempt to add emotional content, strong storytelling and art direction to it. We have tried to achieve a cinematographic experience to show that a solid narrative is not at odds with architecture films. Landmark is not an architecture animation but an architecture movie" [8] [Beauty and The Bit 2018].

In describing the development of the visual project, Victor Bonafonte argues the extreme importance of using a cinematographic language in architecture. In this case, the inspiration is by directors such as Stanley Kubrick, Ridley Scott, Denis Villeneuve, and, more generally,

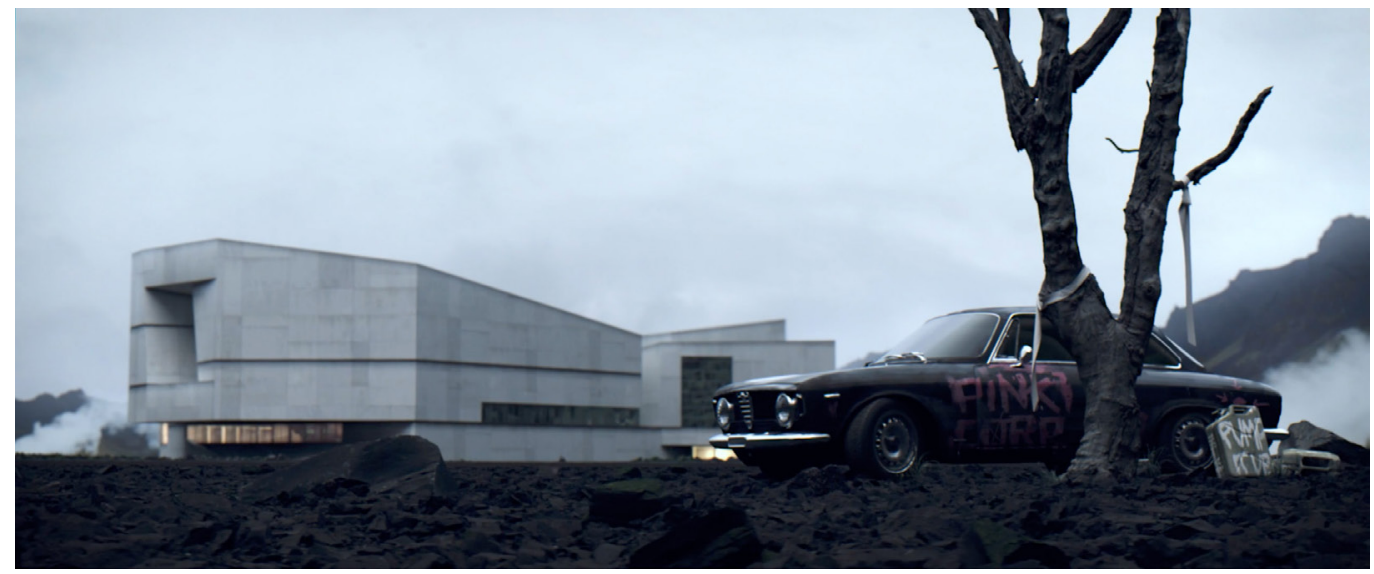

science fiction. The development of the animation project also followed the canonical phases of film production. From the script, the subject of the story emerges, a computer technician working for a mega server in a building isolated in the void. The structure of invention is set in a northern landscape (fig. 9) inspired by lceland. The pre-production phase (pre-viz) saw the use of 3D models, both of the landscape and the building, animated and displayed on the screen in the most straightforward shading modes such as Gouraud or hidden line (fig. 10). In the production phase, on the other hand, the Spanish Studio investigated the shapes of the main building, which is conceived and designed precisely with storytelling [9].

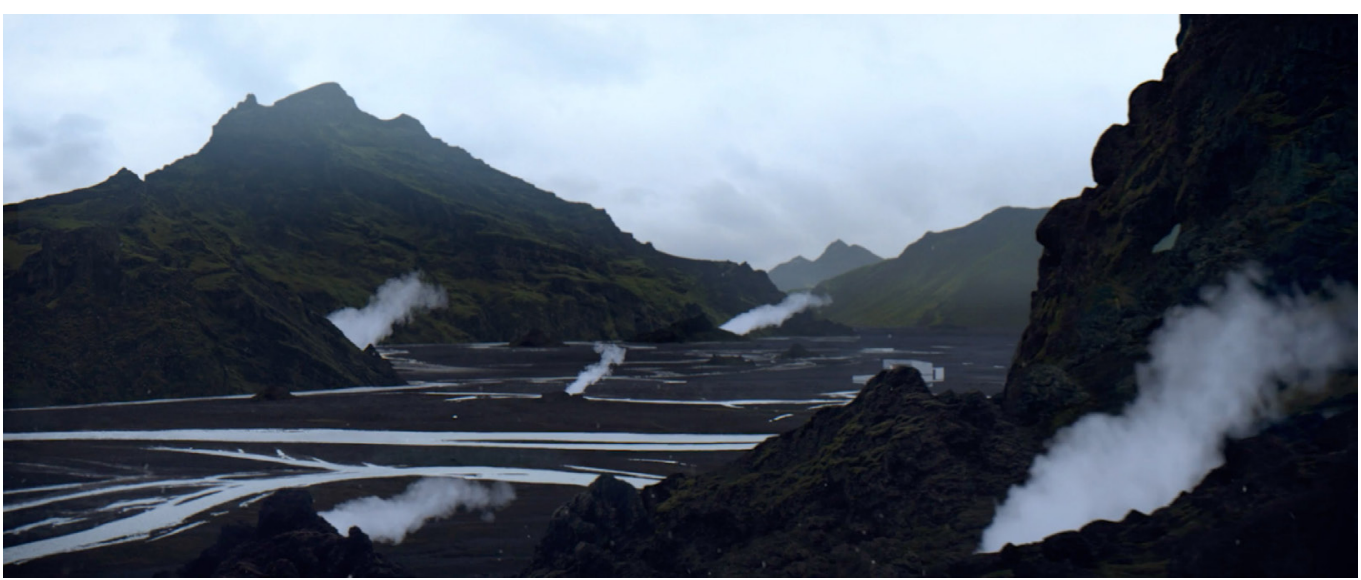


Fig. 10. Beauty and The Bit, Landmark, 2018. Above: the simplified view of the model used during the pre-production phases to study the main sequence plans. Bottom: a frame of the film with the rendering of the scene provided with textures, $3 \mathrm{~d}$ assets and post-production.
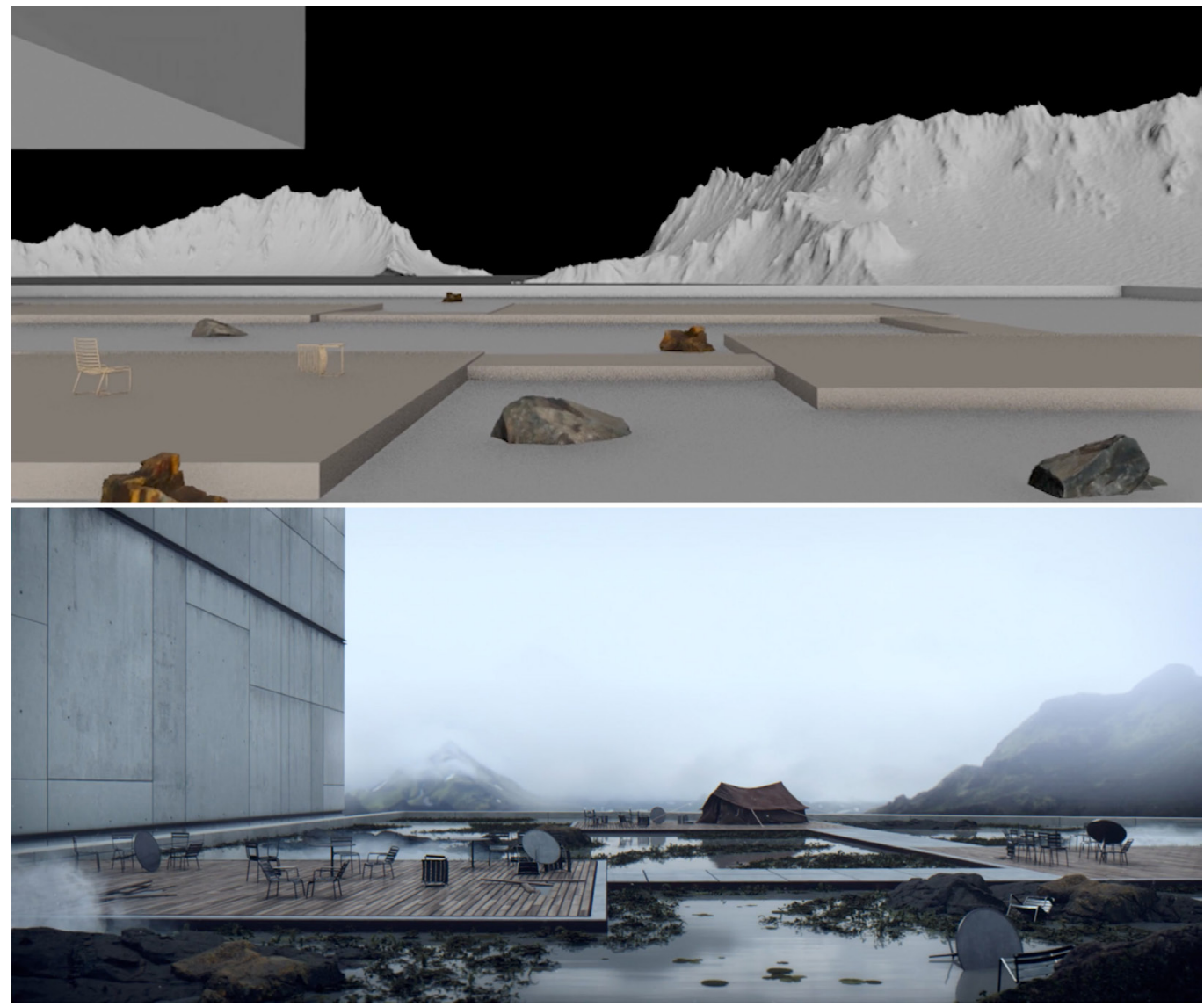

The numerous 3D design proposals of the building, visualized through quick clay-renders (fig. I I) can be said to represent the most exciting part in the film development. Here are shown the possibilities that $3 \mathrm{~d}$ model proves to have when it is combined with the visual development of the architectural project. In Landmark (fig. 12), the use of artistic direction and storytelling guide the rendering of architecture in his animated story. Bonafonte himself says that "an image without artistic direction is impersonal, it is something that anyone else could have done" [Beauty and The Bit 20 I7]. Jeff Mottle, CEO of CGarchitect and authoritative opinion in the archviz is also of the same idea, which states that over the last twenty years the advances and the new technological tools, made more comfortable to use, have taken on an increasingly marginal role in the $3 \mathrm{D}$ industry, while the ability to emerge in the sector depends on the individual talent of the CG artist and his ability to differentiate himself through his own language.

"That was the next major turning point in the industry.That's when the people who also had a talent in lighting, photography, and storytelling started to distinguish themselves from the rest of the crowd. The companies that do the best work now are the ones that probably do at least $50 \%$ of their work in post. The work that they do is very cinematic in their treatment and the way they approach things. Those are the companies, for the most part, that are still around today. The successful ones, the ones that survived the recession, are the ones that have been able to diversify themselves" [Feldman 20I3].

In this scenario, the confrontation between cinema and post-production techniques -the latter being widely used in 3d environments for architectural CG film- merely confirms the profound links between the visual arts and architectural visualization. 


\section{Conclusion}

In this survey, we wanted to highlight how the incisiveness of architectural communication depends on the central role that the landscape has assumed with the perception of architectural space. Image-making through a computer is therefore linked to a cultural and intellectual component, as well as a technical one. In the 2000s, we saw how the phenomenon of

Fig. II. Beauty and The Bit, Landmark, 2018. A the volumetric ch test the volumetric choices of viewpoints of cameras.
Fig. I I. Beauty and The Bit, Landmark, 20 I 8. The interior spaces show the server where only a computer technician (IT guy) manages the work of the structure.

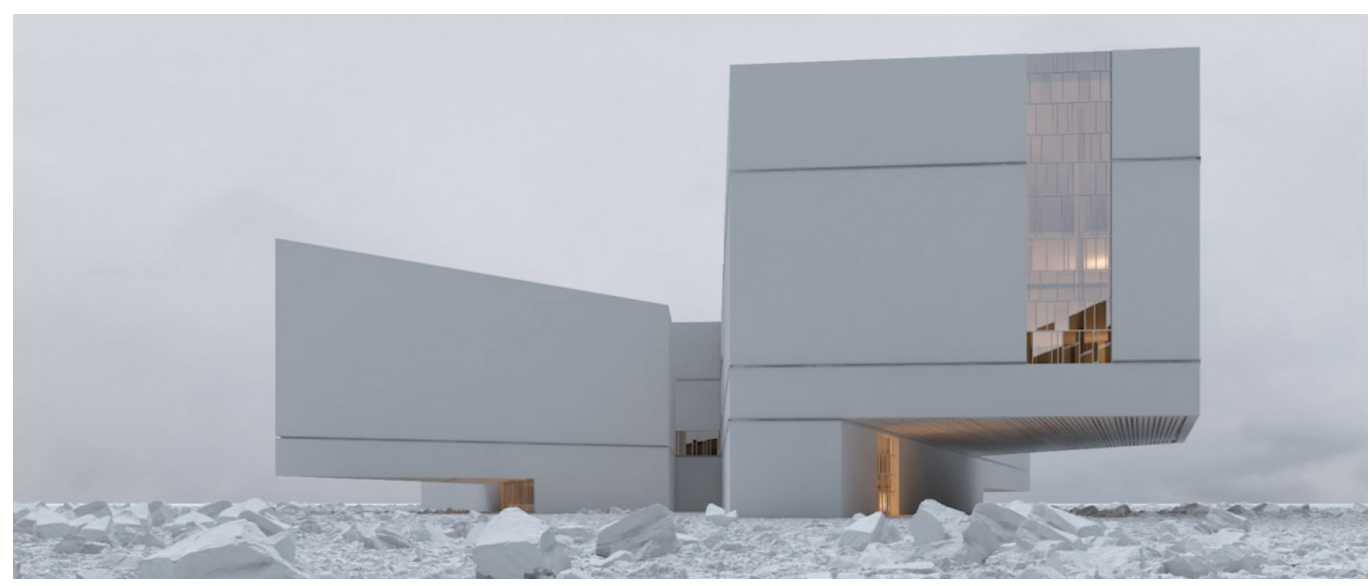

natural visualization imposes itself as a trend. The images of this typology are characterized by using visual strategies recurring in the pictorial tradition and visual arts. In the illustrations examined in this text, was identified the use of digital painting, photo compositing, and matte painting. The combination of these techniques has made it possible to broaden the expressive register of natural visualization, in which many similarities can be traced to the eighteenth-century landscape painting, the English topographical tradition and the representation of the landscape matured during Romanticism. In essence, it is to the ecstatic use of the landscape that the visualizers recur to sublimate and contemplate the beauty of the places, putting architecture in second place as a residual element of the composition. The parts coming from the rendering output become more and more limited. At the same time, the natural landscape and the atmospheric conditions that contribute to characterize the drama of the represented scene are most used and recreated with compositing techniques and more artistic consciousness. To adopt the language of natural visualization were -and still continue to be- the leading companies active in archviz, and we can consider the phenomenon as one of the main factors of the general tendency to the homologation and visual uniformity of the contemporary rendering.

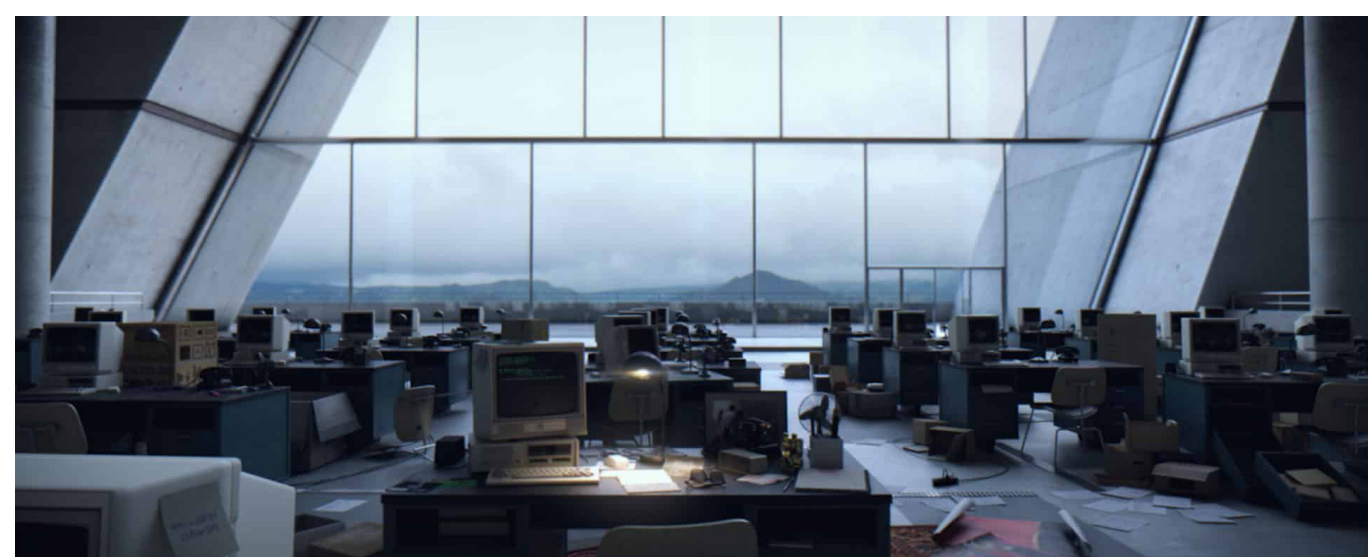




\section{Notes}

[I] See: Farinella 2019, pp. 33-45

[2] See: Haroz, Kwan-Liu 2006.

[3] Farinella 2019, pp. 19-32

[4] Melcher 2014.

[5] MirWay. In: Mir. https://www.mir.no/info/ (the short descriptive text was later replaced by the Norwegian study).

[6] MirWay. In: Mir. https://www.mir.no/info/ (the short descriptive text was later replaced by the Norwegian study).

[7] Immanuel Kant (1993). Critica del giudizio. Torino: Utet, pp. 234-238.

[8] Beauty and The Bit (2018). Landmark: <https://vimeo.com/288 I35384>.

[9] Beauty and The Bit (20।8). Landmark The Journey (Making of): <https://vimeo.com/288/40838>.

\section{References}

De Luise Fulvia, Giuseppe Farinetti (20।0). Lezioni di storia della filosofia. Bologna: Zanichelli.

Farinella Cristian (2019). L'immagine costruita. La formazione, il ruolo e le tecniche del CG artist nella visualizzazione architettonica. Tesi di dottorato presso il Dipartimento di Storia Disegno e Restauro dell'Architettura. Sapienza Università di Roma.

Feldman Stuart (20 I3). Interview With Jeff Mottle Of CGarchitect.com. In ReviewStudio. Blog: <https://www.reviewstudio.com/ blog/interview-with-jeff-mottle-of-cgarchitect-com/>.

Haroz Steve, Kwan-Liu Ma K. (2006). Natural Visualizations. In EuroVis 2006. The Eurographics Association: <https://doi. org/l0.23I2/NisSym/EuroVis06/043-050>.

Honeyball Simon (2015). Special Effects: New Histories, Theories, Contexts. London: Palgrave (Kindle Edition).

Melcher Henry (2014). From fireworks to kayaks, step inside the well-produced world of renderings. In: The Architect's Newspaper: <https://archpaper.com/20 |4/07/from-fireworks-to-kayaks-step-inside-the-well-produced-world-of-renderings/>.

\section{Website}

Beauty and the Bit, studio di visualizzazione di Madrid, fondato daVictor Bonafonte e Lina Garau: <https://www.beautyandthebit. com>.

Bloomimages, studio di visualizzazione fondato nel 2008 con sedi a Berlino e Amburgo (Germania) :<https:// www. bloomimages.de>.

Engram, studio di visualizzazione con sede a Faenza fondato da Paolo Zambrini, che opera nell'archviz dal 1990:<http:/www. engram.it/album/architecture/>.

K2 Visual, studio di visualizzazione fondato da Andras Balogh con sede a Budapest (Ungheria): <http:// k2visual.com/\#>.

Landmark, CG film realizzato dallo studio di visualizzazione spagnolo Beauty and The Bit e pubblicato online nel 20 I 8:<https:// vimeo.com/288|35384>.

LandmarkThe Journey (Making Of): <https://vimeo.com/288|40838>.

Megascans, libreria online della Quixel che contiene numerose scansioni di materiali, terreni, e vegetazione, basate sul modello PBR (physically based rendering): <https://quixel.com/megascans>.

Mir, studio di visualizzazione norvegese: <https://www.mir.no>.

\section{Author}

Cristian Farinella, Sapienza Università di Roma, cristian.farinella@uniromal.it

To cite this chapter. Farinella Cristian (2020). L'esperienza del paesaggio nella natural visualization/Experience of Landscape in Natural Visualization. In Arena A., Arena M., Brandolino R.G., Colistra D., Ginex G., Mediati D., Nucifora S., Raffa P. (a cura di). Connettere. Un disegno per annodare e tessere. Atti del $42^{\circ}$ Convegno Internazionale dei Docenti delle Discipline della Rappresentazione/Connecting. Drawing for weaving relationships. Proceedings of the 42th International Conference of Representation Disciplines Teachers. Milano: FrancoAngeli, pp. 445-466. 